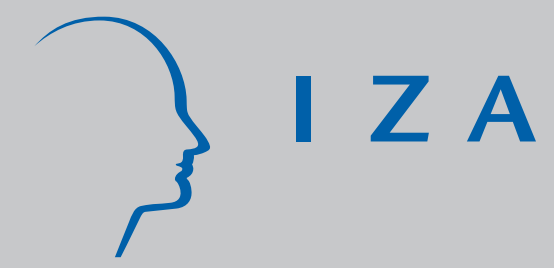

IZA DP No. 286

First- and Second-Generation Migrants in Germany -

What Do We Know and What Do People Think

Michael Fertig

Christoph M. Schmidt

April 2001 


\title{
First- and Second-Generation Migrants in Germany - What Do We Know and What Do People Think
}

\author{
Michael Fertig \\ University of Heidelberg and IZA,Bonn \\ Christoph M. Schmidt \\ University of Heidelberg, CEPR-London and IZA, Bonn
}

Discussion Paper No. 286

April 2001

\author{
IZA \\ P.O. Box 7240 \\ D-53072 Bonn \\ Germany \\ Tel.: +49-228-3894-0 \\ Fax: +49-228-3894-210 \\ Email: iza@iza.org
}

This Discussion Paper is issued within the framework of IZA's research area Mobility and Flexibility of Labor Markets. Any opinions expressed here are those of the author(s) and not those of the institute. Research disseminated by IZA may include views on policy, but the institute itself takes no institutional policy positions.

The Institute for the Study of Labor (IZA) in Bonn is a local and virtual international research center and a place of communication between science, politics and business. IZA is an independent, nonprofit limited liability company (Gesellschaft mit beschränkter Haftung) supported by the Deutsche Post AG. The center is associated with the University of Bonn and offers a stimulating research environment through its research networks, research support, and visitors and doctoral programs. IZA engages in (i) original and internationally competitive research in all fields of labor economics, (ii) development of policy concepts, and (iii) dissemination of research results and concepts to the interested public. The current research program deals with (1) mobility and flexibility of labor markets, (2) internationalization of labor markets and European integration, (3) the welfare state and labor markets, (4) labor markets in transition, (5) the future of work, (6) project evaluation and (7) general labor economics.

IZA Discussion Papers often represent preliminary work and are circulated to encourage discussion. Citation of such a paper should account for its provisional character. 
IZA Discussion Paper No. 286

April 2001

\section{ABSTRACT \\ First- and Second-Generation Migrants in Germany - What Do We Know and What Do People Think}

This paper provides a snapshot of the stock of immigrants in Germany using the 1995 wave of the Mikrozensus, with a particular emphasis on distinguishing first- and second-generation migrants. On the basis of this portrait, we draw attention to the empirically most relevant groups of immigrants and review the received literature on economic migration research in the three principal avenues of migration research. The aspect which we concentrate on in our empirical application, the welfare dependence of immigrants, is a matter of intense debate among economists and policy makers. We contrast the very moderate actual public transfer payment dependence of migrants to Germany with the perception of migrants dependence on public assistance by Germans from various population strata.

JEL Classification: J61, J15, I30

Keywords: Immigration, public transfers, attitudes

Christoph M. Schmidt

Department of Economics (Econometrics)

University of Heidelberg

Grabengasse 14

69177 Heidelberg

Germany

Tel.: +49-6221-54 2955

Fax: +49 6221543640

Email: schmidt@uni-hd.de 


\section{Introduction}

Ten years after German re-unification, and more than fifty years after World War II, German society has transformed its composition to an extent that the founding fathers of post-war Germany could not have anticipated. Certainly, much of this change is a reflection of the international developments, most notably European economic and political integration, the demise of socialism in Eastern Europe, the consequences of post-war baby booms and baby busts, and the ensuing population ageing. Yet, German society in particular has been shaped by the intense and multi-faceted immigration experience, leading to the variegated society we observe today.

The early German post-war migration experience has been dominated by migration streams from Europe's South, with a clear focus on labor migration. However, the ethnic composition of immigration to Germany has changed over time. Europe as a whole, and Germany as its largest immigration country, has become a net receiving region, and the geographic and cultural distances to the immigrants' countries of origin have increased significantly. As a consequence of this continuous influx, German society today not only contains a large immigrant population. Most importantly, second-generation migrants are a sizeable fraction of the German population. It is reasonable to fear that, if their integration is hampered, this will set off a process of transition from immigrant communities to ethnic minorities and such a climate might make it difficult to prevent second-generation immigrants from persistently becoming second-class citizens.

Yet, despite its paramount relevance for all European countries, almost no research has targeted the question of second-generation migrants' integration into society, neither in comparison to the integration of their parents' generation nor to natives of the same age, nor are the potential consequences of different policies regarding the participation of secondgeneration migrants in the political process fully understood. To help reducing this gap, this paper will contribute to the received literature on immigration to Germany - which tends to concentrate on the labor market performance of first-generation migrants - by providing an overview on the existing research, with an explicit focus on distinguishing results for firstand second-generation immigrants. Moreover, this paper offers empirical evidence regarding a matter of intense current debate among economists and policy makers, the dependence on social assistance programs by different immigrant generations. To address the issue of integration most cogently, we contrast the empirical facts with the perception of native Germans regarding this social assistance dependence. 
As a basis for this discussion we draw up a balance sheet of sorts regarding the stock of non-citizens in Germany, distinguishing between foreign-born and German-born non-citizens (first- and second-generation immigrants) using the German "Mikrozensus" 1995 (section 2.2). Specifically, we provide a description of both generations regarding demographic structure, year of immigration, gender and family status, education profile, income and other socio-economic characteristics. This portrait, in combination with the historical background given in section 2.1 enables us to identify the immigrant groups relevant enough to warrant a separate empirical analysis. Following a brief overview on the three principal topics in the area of migration research (section 3.1), we use section 3.2 to as comprehensively as possible answer the question: What do we know about the relevant groups of non-citizens in Germany and clarify which research questions remain open at the time being. In section 4.1 we provide detailed empirical evidence on the actual public transfer payment dependence of migrants, and contrast these findings with the perception of migrants' dependence on public assistance by German natives (sections 4.2 and 4.3). The final section offers some conclusions and outlines further directions of research.

\section{The Immigrant Population in Germany}

This section provides a comprehensive statistical portrait of the population of first- and second-generation immigrants in Germany in 1995. As a first step in this endeavor, we will briefly outline the historical experience of immigration to Germany in more detail. The second sub-section condenses the wealth of individual-level information on both immigrant generations into a set of central demographic and socio-economic characteristics and compares them with that of German natives. Moreover, given this characterization and the historical background of immigration to Germany, we identify the most important - in terms of quantitative importance - immigrant groups currently living in Germany. The following section then surveys the existing evidence in the received literature on Germany, regarding the three principal areas of economic migration research, with emphasis on the distinction of migrants from the first and the second generation.

\subsection{Historical Background}

The history of immigration to Germany after World War II can sensibly be divided into four periods (see SCHMIDT AND ZIMMERMANN (1992)). The years from the end of World War II to the early 1960's were characterized by the post-war migration flows which were triggered by the massive disruption caused by Europe's two world wars. During the first post-war years, 
until about 1950, these flows consisted mainly of displaced people of German ethnicity originating in Eastern Europe. Thereafter, West Germany was affected by migration of ethnic Germans from Eastern Europe leaving the Soviet occupation zone in the East having arrived there from Eastern Europe, and of Germans originating directly from this eastern part of Germany (see SCHMIDT (1996)). The second period from 1955 to 1973 was characterized by labor migration within Europe from the Mediterranean to the northern countries and - to a lesser extent - the immigration of labor from overseas. During this time, Germany actively recruited "guest workers" from several selected European countries (Italy, Spain, Greece, Turkey, Portugal and Yugoslavia), as well as from Morocco and Tunisia. The principal idea behind this recruitment effort was to retain the remarkably strong manufacturing-led growth performance of the German economy despite shortages of manual labor. Excess demand for labor emerged during the 1960s and was not compensated by a sufficient increase in female labor force participation which one could observe elsewhere (see e.g. CARLIN (1996)). Thus, in these years immigration to Germany was clearly dominated by demand-oriented migration incentives due to labor shortages, a characteristic necessarily impinging upon the potential of any supply-side oriented model trying to explain extent or composition of immigration flows. This aspect is the more remarkable, as contemporaneous migration research - with its focus on the US experience - almost exclusively rests on supply-side reasoning when explaining in terms of an economic model how immigrant skill composition, observed as well as unobserved, changes over time (see e.g. BORJAS (1991)).

In fact, the conceptually very powerful Roy model has been the workhorse model of research on migrant performance ever since BORJAS' (1987) article, and has been behind most of the discussion on declining relative immigrant "quality" and "cohort effects" (see also section 3.1 below). A brief look at German immigration history demonstrates how inappropriate a direct translation of this debate would be to the German context: the "guest workers" of the 1960s were deliberately selected to be manual workers, so one should not attribute the low fraction of brain surgeons among them to any sophisticated mechanism of immigrant self-selection.

The middle of the 70's, especially the year 1973, constitutes a fundamental regime switch, a development which was triggered by the first oil crisis and the ensuing economic problems, not only in Germany, but throughout the developed world. For instance, a large literature documents and analyzes the abrupt slowdown in US productivity after 1973 (see e.g. BAUMOL ET AL. (1989)), a phenomenon that was apparently left its trace until the middle of the 1990s. In Germany, one of the major actions to the first oil price shock and the beginning of a 
recession was that the recruitment of guest workers was stopped and immigration was restrained. Similarly, all across Europe immigration policy was tightened by setting up a broad range of institutional barriers to immigration from outside Europe. Only two major channels of legal immigration to Germany remained: family reunification and applying for asylum. Apparently as a reaction to the suppression of other channels, one could observe a surge in asylum seekers and refugees. On the other hand and in contrast to such outsidebarriers the EU and its predecessors fostered internal migration in Europe, e.g. by EU-wide acknowledgment of university diplomas and formal training. The fourth, most current period of immigration to Europe started at the end of the 1980's with the dissolution of socialism and has led to an increased inflow of people from Eastern Europe. In addition, the civil war in Yugoslavia has triggered a new surge of refugees and asylum seekers migrating to Europe.

\subsection{The Population of Non-Citizens in Germany 1995}

The following portrait of immigrants residing in Germany in 1995 is based on the information collected in the 1995 wave of the German Mikrozensus. The aim of this sub-section is to describe both immigrant generations by the most interesting socio-economic characteristics and to compare them to native Germans. It becomes transparent through this descriptive evidence that not only natives and immigrants are very different, but there is considerable heterogeneity among the immigrants themselves. We distinguish individual-level characteristics falling into three groups of indicators: (i) demographic indicators, (ii) labor force indicators, and (iii) information on income and income sources.

\section{Demographic Indicators}

Figure 1 displays the age distribution of first- and second-generation immigrants as well as that of native Germans. Clearly, this current age distribution has been shaped by immigration history - variations in the magnitude of immigrant influx and typical age at immigration - and by demographic behavior. Specifically, whether and at what age first-generation immigrants might return to their country of origin has been a matter of intense research (see e.g. DusTMAnN (1996), SCHMIDT (1994), and SCHMIDT (2000)). The migrants' choice regarding their fertility - with frequency and timing as its principal components - has been researched less intensely. In particular, it is difficult to assess whether migrants' demographic behavior tends to adopt quickly to that of the indigenous population. On average, the second generation of immigrants is considerably younger than the first generation which is in turn younger than the native population. Moreover, the majority of first generation immigrants was in its prime 
age, i.e. in the age group between 15 and 35 years, at the time of entry to Germany (cf. Figure 2).

If all immigrants remained in the destination country for their whole lifetimes, the distribution of years of entry in the current migrant population would predominantly reflect fluctuations in aggregate immigration intensity (and, of course, old-age mortality). Yet, due to the large emigration flows which accompanied large-scale immigration throughout the last decades (Schmidt (2000)), recent immigrants tend to dominate the migrant population numerically. Figure 3 displays the year of immigration of the 1995 population of immigrants in Germany. Around 50\% of this stock immigrated after 1978 whereas only $40 \%$ who were still residing in Germany in 1995 entered the country prior to the recruitment stop in 1973. For this reason it seems appropriate to reject the idea of the migrant population in Germany consisting mainly of workers who arrived as guest workers and decided to stay. Rather, this population is a mixture of former guest workers, their families, and - to a large extent - of more recent immigrants with other motives for immigration and from other origin countries.

The upper panel of Table 1 reports the geographical distribution of first- and secondgeneration immigrants at the level of the federal states (Bundesländer). The lower panel reports the distribution of immigrants by citizenship. The majority of first- as well as secondgeneration immigrants concentrates in the two southern states Baden-Württemberg and Bayern as well as the largest state Nordrhein-Westfalen. Both southern states are highly industrialized states and have had lower unemployment rates than the national average. In contrast, the industry structure of Nordrhein-Westfalen has been dominated by the mining and steel industries which were actively recruiting manual labor in the 1960's and the beginning of the 1970's.

By far the largest first-generation immigrant groups are Turks, followed by Yugoslavians and immigrants from the other European guest worker countries (Italy, Greece, Portugal and Spain). For the second-generation, this ranking changes somewhat. Turks are also the largest group, but the other guest worker countries are providing the second largest group. This is apparently due to the increase in refugees from Yugoslavia following the civil wars in the beginning of the 1990's, which may have increased the number of first-generation immigrants from Ex-Yugoslavia considerably.

\section{Labor Force Indicators}

Table 2 reports the highest schooling degrees and formal training levels of immigrants and natives. At first glance, one would perhaps expect that the relatively low educational 
endowments of the first generation of immigrants - after all, many of these migrants were recruited as manual workers (SCHMIDT (1997)) - would be mitigated substantially in the second generation. Yet, somewhat surprisingly, the share of second-generation immigrants reporting a higher schooling degree is substantially lower than that of native Germans and that of first-generation migrants. This apparent contradiction of the "natural" convergence hypothesis is interpreted as an indicator of "dissimilation" - to express the opposite of assimilation - between natives and foreigners born in Germany by RIPHAHN (2000). If this were the correct interpretation, the policy implications would be enormous. Integration measures aimed directly and exclusively at the second generation should be implemented with priority over all alternative integration programs or initiatives paid from the public budget.

However, in interpreting this information one should bear in mind that almost all secondgeneration migrants received their schooling degrees in Germany, whereas typically a substantial part of the first-generation migrants did not. The direct comparability of schooling degrees across countries and the transferability of the implied human capital from one country to another are heavily debated topics in the received literature. Thus, the comparison of reported schooling degrees between natives and first-generation immigrants has to be handled with caution. It seems reasonable to presume that - in terms comparable to the associated German degrees - among first-generation immigrants the highest formal training level is overstated as reported in the lower panel of Table 2 . These measurement problems notwithstanding, a further noticeable feature arguing against the "dissimilation" hypothesis is the remarkably low share of second-generation migrants without any formal training and the relatively high share with a formal vocational training degree - a concentration on years of education seems somewhat misplaced for judging this issue. The treatment or even correction of the measurement problems described above awaits further research - it will be difficult at the conceptual level, though, to separately identify genuine human capital investment abroad and inter-generational tendencies to invest in education.

In line with these observations is the distribution of immigrant groups and natives across selected industry sectors (cf. Table 3). Here as well we would have expected convergence across natives and the children of migrants. The sectoral distribution as well as the unemployment rate of the second generation indeed resemble much more those of the native Germans than could be observed for those of the first generation. The first generation which was to a large part actively recruited to perform manual work in the German manufacturing industry is predominantly still employed in this sector as well as in the food and beverages sector. Together with the construction sector these two sectors comprise more than one half of 
the employed first-generation immigrants. For natives as well as second-generation immigrants, however, these three sectors only account for slightly more than one third of the employed, respectively.

\section{Income and Income Sources}

The level of household income and its sources are important indicators of the economic well-being and performance of different population strata (see e.g. BIEWEN (2000)). Figure 4 displays the distribution of household income for natives and immigrants. Unfortunately, the Mikrozensus contains only categorized income information. However, this income distribution is more right skewed for natives than for second-generation migrants which in turn is more right skewed than that of the first generation.

Table 4 reports the primary sources of income for immigrants and natives. A remarkable pattern is the high share of natives for which pensions are the primary income source. A considerable share of first- as well as second-generation immigrants, however, report social assistance payments as main income source. Such a result would seem to vindicate translating to Germany the serious concern with rising immigrant welfare dependence which is raised in the US literature on immigration. Yet, German post-war immigration history was very heterogeneous, and it would be important to know who exactly is disproportionally dependent on social assistance. For instance, if one found that the low-skilled workers recruited for manual labor in the 1960s - or their descendents - are typically in lower social rungs, the relevant comparison would be with native unskilled. Similarly, if welfare dependence was mainly a phenomenon of asylum seekers, this would be a question of legislative design, rather than a reflection of self-selection mechanisms. These issues are taking center stage in the empirical part of this paper. Moreover, a substantially higher share of the immigrant population reports work income. That is, notwithstanding our reservations at taking mean outcomes at face value, the first step of analysis should be the formation of a balanced view displaying more clearly welfare dependence and active labor market contribution by immigrant group.

\section{Relevant Immigrant Groups in Germany}

Given this overview of the stylized facts and the historical background provided above, the following immigrant groups in/to Germany should be distinguished for purposes of any deeper empirical analysis: (i) ethnic Germans who immigrated directly after WW II, (ii) recruited guest workers, (iii) immigrated family members of the guest workers, (iv) 
permanently and temporarily accepted asylum seekers and refugees, (v) ethnic Germans who immigrated after 1990, (vi) migrants from within the EU utilizing the free movement agreement, (vii) legal temporary workers (e.g. seasonal workers) mainly from Eastern Europe, (viii) illegal migrants, and (ix) children of these immigrant groups being born in Germany (the second generation).

Legal temporary workers (vii) are of quantitative negligible magnitude. Their access is tightly restricted to only some thousand people per year which can be recruited for specific industry sectors on the basis of temporary formal work contracts. A repeated admission of these contract workers is usually not possible (see regulations in $\S 10$ Ausländergesetz, and several statutory orders concerning work permissions and exceptions from the recruitment stop). For illegal migrants (viii) there are no reliable figures available. The only data source for this group are the apprehensions of German border police. On average these were around 34,000 people per annum between 1995 and 1999. The actual share of illegal immigrants living in Germany might be higher, but an assessment of this number is of highly speculative nature. The other immigrant groups can be identified in available micro data, and can be analyzed separately in empirical studies.

\section{Economic Migration Research - The State of the Discussion}

\subsection{Migration Research - Three Principal Topics}

Economic research concerning migration issues can be conceptualized into three broad fields, each of them interrelated with each other. All these research areas carry important implications for immigration policy, again reflecting an intimate relationship between them. These fields may be described most sensibly by the following set of research questions:

1. Which factors determine the decision to migrate, i.e. which are the motives or driving forces behind observed immigration flows ? Naturally, since the decision to migrate is in all likelihood the outcome of a systematic process, the characteristics of those who decide to relocate from their original home to a new destination are hardly a random sample of the indigenous population of either country. Understanding the composition of migration flows seems therefore to be an important prerequisite for the analysis both of migrant performance and the impact of immigration.

2. Which factors determine the economic performance of immigrants in the destination country, i.e. for instance do wages or employment prospects of immigrants converge or diverge as the duration of residence unfolds if compared 
to that of natives and what are the reasons for these developments? A related aspect is the degree of discrimination against immigrants as well as the degree and the consequences of geographical and/or occupational segregation, i.e. the clustering of immigrants or specific immigrant groups in certain geographical areas or occupational groups.

3. Which factors determine the economic impact of immigration on the population indigenous to the destination country, i.e. does immigration reduce the wages or employment prospects of e.g. low-skilled natives or resident migrants of preceding entry cohorts, and if so, what are the mechanisms at work? A related aspect are the determinants of the perception of as well as the attitudes towards immigrants by the natives in the destination country.

\subsection{Evidence for Immigration to Germany}

\section{The Decision to Migrate}

Evidence for the determinants of immigration to Germany is quite scarce, and if available, only at the aggregate level. VOGLER AND ROTTE (2000) follow the traditional literature on explaining aggregate migration flows (see, e.g. HARRIS AND TODARO (1970) for a seminal study) by differential developments of economic activity (per capita), unemployment rates and other socio-demographic factors, such as geographic distance. Pinning down any stable relationship between the economic factors and immigration activities has been notoriously difficult throughout this literature. This has made the creation of a satisfactory connection between the in parts overwhelmingly sophisticated economic theory of the migration decision (see e.g. Stark (1991) or Berninghaus And SeIfert-Vogt (1991)) and the - at best scarce evidence for the validity of its predictions a very frustrating endeavor. VOGLER AND ROTTE (2000) escape from this dilemma - which also plagues their study - by altering their focus in an innovative way: Their analysis explicitly addresses the issue whether political oppression in the country of origin fosters the decision of potential emigrants, with particular emphasis on the role that the current state of economic development plays for this process.

With the aim of predicting future immigration activity in case of the enlargement of the EU to the East, FerTiG (1999) uses an empirical specification derived from a stripped-down theoretical model of the migration decision. He concludes that economic differences exhibit only a moderate influence on actual migration activity. Finally FERTIG AND SCHMIDT (2000) take a completely different approach at modeling aggregate immigration activity, also with the principal aim of forecasting net immigration into the future. In this study, the crucial role 
of demographics for migration activity is placed in the focus of the discussion. It has been demonstrated in numerous empirical analyses of migration activity - historical as well as recent - that migrants tend to move from origin to destination at young prime age. Figure 2 exemplifies this phenomenon for the German case. Thus, the relative prevalence of this age group in the population at the origin is necessarily a major determinant of the actual migration potential and, in consequence, activity from this source. On the basis of these considerations, FERTIG AND SCHMIDT (2000) conclude that even if EU enlargement were to lift all legal obstacles for East-West migration, the ensuing migration flows would likely be only of moderate magnitude.

At the present time, there is no study of international migration to Germany at the individual level. The primary reason for this gap is the missing data base, as any serious empirical study would require micro data at both origin and destination.

\section{Performance and Discrimination}

Skills play a dominant role for immigrant performance, whether acquired in formal curriculae as secondary or post-secondary schooling and vocational training, or informally as experience in the labor market, or as manifestation of intrinsic personal traits such as cognitive ability or motivation. The modern literature on immigrant performance dates back to CHISwICK (1978) who regressed labor earnings, the natural measure of labor market performance - at least in the US context - on years of formal education, immigrant status, and a polynomial on duration of residence in a cross-sectional census extract comprising native and migrant workers.

His results demonstrate clearly that for the US, ceteris paribus, a comparison of native with immigrant workers reveals earnings differences that vary systematically with duration of residence in the country. While the most recent immigrant workers typically experience a substantial wage disadvantage, this gap is smaller for earlier immigrant cohorts. CHISWICK (1978) even found immigrants with a long duration of residence in the US to display an earnings advantage. While this latter result is less robust, an earnings gap that decreases in the duration of residence has been a stable empirical phenomenon in all subsequent crosssectional studies for the US. The really challenging issue, though, is the interpretation of this pattern. Building on human capital theory, CHISWICK (1978) provided a very convincing structural interpretation: in the absence of any noticeable form of discrimination - an absence that seems to be a natural presumption in the context of the American "melting pot" (but see below) - wages directly reflect individual productivities. 
Immigrants acquire productive capacity in their origin country, but only part of this human capital can be transferred to the labor market at the destination. Consequently, the young adults arriving at their new home possess a lower earnings capacity, and - since their labor supply is typically inelastic - relatively low wage earnings. Over their time of residence, they tend to acquire the lacking human capital, such as the language spoken at the destination their low initial earnings capacity implies that the opportunity cost of their investment are relatively low, making substantial human capital acquisition likely. In addition, CHISWICK (1978) attributed the observed overtaking of experienced migrants' over natives' wages to a positive selection in terms of unobserved covariates.

In stark contrast to this positive assessment of immigrant performance, BORJAS (1985 and 1987) emphasizes the necessity to account for cohort effects when trying to measure the dynamics of immigrant wage earnings. Specifically, his empirically work demonstrates that earlier cohorts of immigrants to the US display a better economic performance - compared to contemporaneous native workers - throughout their residence than more recent cohorts. In fact, BORJAS (1985) attributes most of the cross-sectional earnings profile in duration of residence to such cohort effects (for a different view see LALONDE AND TOPEL (1992)).

Specifically, most recent cohorts apparently perform very poorly when compared to earlier cohorts at their time of immigration. In his 1987 paper, BORJAS motivates this development on the basis of the prototypical Roy model of selection applied to the migration context. Most of the decline in immigrant quality is attributed to the changing country-of-origin mix which has shifted more and more to Latin America and Asia, and away from the traditional countries of origin in Europe. While the importance of the origin composition of immigration flows seems to be undisputed, the literature remains controversial as to the precise interpretation of the negative changes in unobserved residual terms as declining immigrant "quality", or, for instance, as a reflection of a changing distribution of wages - with declining real wages for unskilled workers in the US providing an important background phenomenon (for a more recent contribution see YUENGERT (1994)).

Both the rather different history of immigration to Germany and the certainly distinct nature of US and German labor markets suggest that a simple translation of US results to the German context is impossible. Several empirical analyses address the issue of wage performance of the guest workers of the 1960s and 1970s in the German labor market of the 1980s and early 1990s, all using, in principle, the same source of micro data, the German Socio-Economic Panel (GSOEP) (see, in particular, DuSTMANN (1993) and SchMIDT(1997)). On balance, these papers demonstrate that in the German labor market formal skills play a 
decisive role for immigrant wage earnings - for instance, SCHMIDT (1997) concludes that those immigrants who received their schooling and post-secondary education in Germany achieve earnings parity with native workers, while the typical first-generation migrant from the "guest worker" countries lags some 20 percent behind the average native worker in terms of wages.

Moreover, any evidence regarding the assimilation hypothesis derived from the US literature - migrants starting out with a considerable disadvantage but catching up quickly - is extremely fragile. DUSTMANN (1993) demonstrates that the distinction of permanent and temporary migrants might be important for the question of earnings dynamics, while SCHMIDT (1997) pursues a non-parametric specification of duration-of-residence effects that reveals no systematic pattern.

Using the ALLBUS (see below) as an alternative data source SCHMIDT (1997) compares migrants from the "guest worker" countries with ethnic German immigrants - concluding that the latter group of immigrants is typically better educated and economically well integrated. Finally, DUSTMANN AND SCHMIDT (2000) is the only paper to address the wage performance of female immigrants. To date, almost the complete migration literature and certainly all studies of the German case have concentrated on the analysis of the economic performance of first-generation male immigrants. In their paper DUSTMANN AND SCHMIDT (2000) place considerable emphasis on the treatment of labor supply issues that plague all analyses of female wage earnings. They conclude that for the relative wages of female immigrants not only their own formal education, but also their family circumstances - most notably the return plans of their family - play an important role.

All these analyses, for Germany as well as in the international context, rest their interpretation on a crucial, and typically completely undiscussed, identification assumption. Wage differences can only be used as a perfect measure of disparities in economic productivity, if the labor market functions without any trace of discrimination and any legal barriers to wage parity, of course. While raising this idea in the context of the US labor market might not stand any chance, and any advance to put only the slightest dent into the American melting pot myth will probably face fiercest opposition, challenging the fundamental identification assumption of no immigrant discrimination seems less daring in the European context.

On the other hand, interpreting any unexplained wage differential as a reflection of discrimination would require an equally strong and hardly more plausible implicit identification assumption - the absence of migrant-native differences in productive capacity 
once formal characteristics are controlled for. Yet, the two identification assumptions discussed here allow the interpretation of reduced-form wage dynamics in terms of structural ideas, assimilation or discrimination, although all the evidence merely pertains to unexplained migrant-native wage differentials. Borjas cohort argument is an additional variant of the same problem: what is the valid identification assumption ? That is, these assumptions must remain untestable, and their validity has to be judged on the basis of economic reasoning. While this issue threatens to remain unsettled, it seems safe to argue that an analysis of relative immigrant earnings which exclusively concentrates on discrimination proceeds on very thin ice. Nevertheless, the consideration of rising discrimination might be an interesting addition to the Chiswick-Borjas debate on cohort effects and declining immigrant "quality".

\section{The Economic Impact of Immigration}

While relative individual economic performance is a matter of direct comparison of an appropriate outcome measure between the individuals of interest - migrants - and a comparison group - natives, the economic impact of immigration unfolds in an indirect fashion via market reactions, and is therefore much more complex as an object of investigation. Conceptually, additional immigration shifts the relevant labor supply curve outward - with the first problem for any empirical strategy arising as the question what exactly is "relevant", the local labor market, the skill group etc. ? The consequences, in terms of employment and wages for this relevant group, as well as for all other groups of labor with unskilled native workers being the most prominent case in the public debate - are first of all a matter of the relative own elasticities of demand and supply and of the set of elasticities of complementarity with all other production factors.

Yet, the additional labor supply is only part of the story, since product demand, and thus labor demand (on all other sub-markets) tend to be affected positively. On balance, it might not be the case at all that immigration harms any group of native workers via the crowding out that the constant output reasoning typically applied seems to suggest. In fact, the matter is entirely empirical. Nevertheless, even at the theoretical level many facets relevant for the real world might complicate the analysis, for instance the necessity to account for an increasing variety of products via immigration, or the consequences of institutionalized wage rigidities (see SCHMIDT ET AL. (1994)).

The empirical challenge is to isolate immigration induced shifts in labor supply which can be treated as if they were set in an ideal experiment, in other words as exogenous. Several strategies can be found in the literature regarding the definition of the appropriate sub-market, 
ranging from time series on aggregate labor markets, over cross-sections of regional labor markets to longitudinal analysis across region and time. The latter "area approach" is certainly the most prominent strategy. Studies also vary in their strategy at pinning down the numerical impact of additional immigration. Reduced-form studies regress outcomes directly on relative shares of immigrant labor, while structural-form approaches first estimate the relevant elasticities of complementarity before assessing the impact of additional immigration in an out-of-sample prediction.

All these analyses face the common problem of non-experimental research: the extent of additional immigration does not vary randomly across time and space, as in a laboratory experiment, but is rather the outcome of systematic forces. Specifically, more attractive destinations will typically generate a larger influx of immigrants. Comparing the relevant economic outcome measures, native employment rates say, across regions will typically confuse the impact of immigration with the underlying reason making the area particularly attractive. Moreover, the indigenous population may be quite mobile, too. Thus, a lacking impact of immigration could be due to compensatory moves of indigenous workers (FILER (1992)).

The literature has proceeded in different directions to address this endogeneity problem. Altonji AND CARD (1991) and LALONDE AND TOPEL (1991 and 1997), for instance, pursue the idea of instrumental variable estimation. Using previous immigrant density as their instrumental variable, these estimates invoke the identification assumption that this variable affects immigration but not its impact on regional labor markets. A related idea has been developed by CARD (1990) for the so-called Mariel boatlift, an idea also applied by HUNT (1992) to the Algeria-France migration of the early 1960s. These studies exploit historically unique events in order to create a "natural experiment". Typically, these studies tend to conclude that the crowding out effects of additional immigration on most native workers are of minor importance. If at all, it is the direct competitors - in terms of formal and informal skills - which are affected most.

For Germany, several empirical studies exist which proceed along similar lines. PISCHKE AND VELLING (1997) follow closely the approach by ALTONJI AND CARD (1991) using regional data for Germany, with particular emphasis on demonstrating the fragility of instrumental variable estimates to the underlying identification assumptions. HAISKENDENEW (1996) and DENEW AND ZIMMERMANN (1994) use individual-level data from the GSOEP, replacing the emphasis on regional labor markets by an analysis of separate industries. Since this approach is necessarily threatened by severe problems of endogeneity, 
the idea of instrumental variables is applied as well. In the light of the data material finding a convincing instrument remains a complex task, though. On balance, these studies tend to display quantitatively minor effects of additional immigration on the economic outcomes of the indigenous population, but considerable controversy remains as to their precise magnitude. BAUER (1998), estimates the relevant elasticities of complementarity in a production-function approach using individual-level data, basically confirming those studies who deny a relevant impact of immigration.

Recently, attitudes towards minorities have become an issue of concern in the economic literature (see e.g. DUSTMANN AND PRESTON (2000)). A brief overview on empirical studies concerning the perception of and the attitudes towards immigrants for the German case is provided in section 4.2 .

\section{The Welfare Dependence of Immigrants - Facts and Perceptions}

\subsection{The Dependence of Immigrants on Public Transfer Payments - What Do We Know}

One of the most contentious issues in the context of immigration and immigration policy regards the welfare state. Indeed, BORJAS (1999) places the debate on immigration welfare dependence on equal footing with the "classical" topics of immigrants' labor market performance and their labor market impact. The concern over this problem in principle reflects legitimate reservations about the fiscal and political viability of a welfare state potentially acting as a magnet to migrants, yet being underwritten by a native electorate. Even though the US welfare system can hardly be compared in terms of its generosity to the German social safety net, the well documented fact regarding the US (see e.g. BLAU (1984), BorJas AND TREJo (1991) and (1993), BorJAS AND HiLton (1996)) that immigrant households have become important clients of the existing welfare programs led to provisions in the most recent 1996 welfare reform which were directed at curbing immigrants' access to the system.

Neither the empirical results regarding the trends in immigrant welfare nor the institutional arrangements shaping the environment for immigrants' welfare use are easily translated from the US, Canada (see e.g. BAKER AND BENJAMIN (1995)) or the UK (see e.g. BLUNDELL ET AL. (1988)) to the German context. Most of all, the historical developments governing size and composition of immigrant influx to Germany were quite distinct. Consequently, the issue is entirely empirical.

Unfortunately, the empirical literature for Germany is rather scarce, with RIPHAHN (1998) being one exception. The author, using data from the GSOEP, reports distinct patterns of 
welfare dependence for foreigners and natives. The estimated differences in the dependence on social assistance payments between foreigners and natives suggest a statistically significant and substantially lower risk of foreigners to depend on these benefits. However, the differences between the foreigner groups were not statistically significant. Moreover, due to the limited number of observations on second-generation migrants in the GSOEP, RIPHAHN (1998) could not distinguish between the first and the second generation. The Mikrozensus provides us with the possibility to provide such a separate analysis.

The German Mikrozensus is an annually 1\% random sample survey of the population residing in Germany conducted by the Federal Statistical Office (Statistisches Bundesamt). The information collected includes standard demographic and labor market variables as well as information on household and individual income and income sources. The public use file of the Mikrozensus is a $70 \%$ random sample of the original dataset containing more than 500,000 observations. Compared to other micro datasets like the GSOEP the Mikrozensus thus has the advantage of a large number of highly reliable observations which allow e.g. the identification of a substantial number of second-generation immigrants. On the other hand, the Mikrozensus is only a cross-section with income categories and no information on "weaker" characteristics, like language ability or attitudes.

Similar to the case of the US it is certainly important to distinguish between the welfare dependence of immigrants to Germany in comparison with those of a typical native household and in comparison with a hypothetical native household with the characteristics of a typical immigrant household. Since the most important socio-economic characteristics are available in our data, we will estimate a model aiming at the explanation of the determining factors of social assistance dependence. The focus of this analysis is on the risk of being dependent on such public transfer payments for non-citizens. Before we proceed with the estimated model, we briefly summarize the German social assistance system and discuss some of the methodological issues in modeling the dependence on welfare payments.

Social assistance is an integral part of the German income support system which is, in principle, based on residency in Germany and not on citizenship. However, since 1994 there have been some exceptions for asylum seekers. The intention of social assistance is to guarantee eligible individuals a minimum income sufficient for living purposes. Social assistance is strictly means-tested and serves as a substitute for other benefit schemes, like unemployment benefits, if the eligibility for those has expired. Financial benefits under the heading of social assistance comprise lump-sum payments for which under regular 
circumstances no repayment requirement is entailed when the financial situation of the supported individual improves again.

In the received international literature on modeling the dependence on welfare payments, the problem of possible non-take up behavior of eligible individuals is heavily discussed. In our case this problem may be important since the residency regulation reform in 1991 provided authorities with the possibility to expel foreigners without a permanent residence permission, if they claim social assistance (cf. RIPHAHN (1998)). This sample selection problem may lead to a bias in the estimated coefficients. However, since there is no information available on the legal status of foreigners in the Mikrozensus we are forced to continue under the proviso that this selection problem is negligible.

In our own analysis we assume that the probability to observe an economically active individual (aged 15 to 65 years) in the state of receiving social assistance payments is determined by the following groups of factors: (i) the household structure, such as living in a single household, the number of children etc.; (ii) individual characteristics, like age, sex, education etc.; (iii) the level of information on eligibility criteria, the amount and duration of benefits etc., for which (following RIPHAHN (1998)) we introduce two indicator variables: living in a small city and living in a big city; (iv) foreigner specific characteristics, like being a first- or second-generation migrant, the duration of residence in Germany etc. Moreover, one would presume that the duration of past dependence on social assistance payments may also have an effect on the probability to observe someone in this state since an individual may be caught in what is sometimes called the "welfare trap". Unfortunately, the Mikrozensus provides no information on the duration an individual has been receiving social assistance.

We estimate a discrete choice model, specifically a binomial probit model, to explain the probability of observing an individual in a certain state by the set of socio-economic variables described above. The dependent variable takes the value of one if an individual reported social assistance as its primary source of income in the 1995 wave of the Mikrozensus, and zero otherwise. All explanatory variables are defined in Table A.1 in the appendix. The focus of our analysis lies on the foreigner-specific variables which comprise dummy variables for different first- and second-generation foreigner groups, information on the duration of residence in Germany for the first generation and interaction variables comprising individual characteristics like age and education for the first and the second generation, respectively. The share of individuals depending on social assistance in our sample is $8.1 \%$ for foreigners whereas only $1.4 \%$ of German citizens reported social assistance as primary source of income. 
Table 5 reports some descriptive statistics for the variables in the sample. With our analysis we address the counterfactual question if the risk of non-citizens to depend on public transfer payments is higher than that of comparable natives conditionally on observable characteristics, such as education or age. Since the composition of the migrant population with respect to these attributes is largely a result of German immigration recruitment policy of the 1960's and early 1970's and its aftermath, a comparison that did not condition on these factors would lack respect for the role of history in shaping current circumstances. By contrast, our approach is designed to reveal whether migrants are different from native Germans in terms of intrinsic, unobservable characteristics, as much of the public debate seems to suggest. Specifically, in our analysis we invoke the identification assumptions that the functional relationship between the risk of dependence and the determining factors is represented by a normal distribution function and that a valid comparison group for foreigners are natives with the same set of socio-economic characteristics.

\section{Estimation Results}

Table 6 reports the estimated marginal effects of each explanatory variable and its associated t-values for our preferred specification. The marginal effects are the changes of the probability of an individual to be observed in state 1, i.e. receiving social assistance, associated with a unit change in the respective regressors, holding all other regressors constant. These marginal effects are the effect of a unit-change in each variable, one at a time, evaluated at the sample means of all variables. To derive a marginal effect for categorical variables, we consider instead of a change at the sample mean a discrete change from 0 to 1 . The preferred specification is the result of a sequence of tests involving linear restrictions on the parameters of the categorical variables, most notably regarding the distinction of variables' effects for first- and second-generation migrants. The null hypotheses that these parameters are equal is rejected at a $1 \%$ significance level for all variables, except for the distinction of "first-generation high education" and "second-generation high education" which are combined into the variable "foreigner high education". The same result holds for the variables "first-generation not employed" and "second-generation not employed" which are comprised in the variable "foreigner not employed". Homogeneity restrictions for natives, first-generation and second-generation foreigners are rejected at a $1 \%$ significance level (see "Diagnostics" in Table 6).

Most of the estimated marginal effects are statistically significant at a $1 \%$ significance level (the critical value is 2.576). Household and individual characteristics paint a clear and 
credible picture about the correlates of welfare dependence. While married individuals are substantially less likely than single adults to be on welfare, single adults with children are somewhat more likely to be on the welfare roles. The likelihood also rises unambiguously with the number of children, irrespective of marital status - the cost of raising children has rightfully been a contentious issue in the population economics literature and the public debate throughout the last decades. Interestingly, East Germans are slightly less likely than West Germans to be on welfare, which is presumably to be a reflection of the different mix of income support programs (early retirement schemes) available in this part of the country.

Regarding personal traits, an inversely u-shaped age profile indicates that welfare dependence is somewhat less prevalent in older age groups. For instance, a one-year increase in age at the sample mean of approximately 42 years implies a decline in the dependence risk of $0.01 \%$. By contrast, for a 30 year old the corresponding marginal effect is a positive $0.06 \%$. The coefficient for the female dummy demonstrates the slightly higher likelihood to receive welfare for women. Education is apparently an important correlate of welfare dependence, as particularly low educated individuals, and those without formal training are found on the welfare roles.

Finally, inhabitants of big cities are more likely to receive welfare, a phenomenon that we attribute in our table to the availability of information on income support schemes and the lower opportunity cost of receiving welfare in big cities. Yet, the full spectrum of underlying reasons for this pattern necessarily remains unexplored.

Our specification also comprises a series of interactions of the substantive variables such as age or education with indicators of first- and second-generation foreigners status, respectively (apart from the two entries "high education" and "not employed", see above). That is, all these marginal effects arise in addition to the effect already displayed in the main section of the table. Thus, for instance, while high education and being not employed both display significant effects on the likelihood to receive welfare, their differential effects for immigrants are negligible - in these respects migrants' and native Germans' reactions are identical.

Regarding the migrants of the first-generation, in a remarkably stable pattern the results demonstrate a slightly lower welfare dependence than for native Germans. Remarkable are also the distinct age patterns, indicating that welfare dependence is particularly unlikely for young adults among the first-generation immigrants. Compared to a 30 year old native, the marginal effect of growing older on the dependence risk more than doubles for firstgeneration migrants of the same age. The associated marginal effect is $0.14 \%$. The 
employment situation apparently also exerts a differential impact on immigrants of the firstgeneration, as the long-term jobless are disproportionally more likely to be on welfare than long-term jobless natives.

For the US a rising duration of residence is apparently a strong correlate of welfare dependence. Quite in contrast, welfare dependence declines significantly as immigrants' duration of residence in Germany proceeds, albeit with declining annual effects. This pattern is certainly to a considerable degree the reflection of institutional regulations, since receiving a work permit at the time of the survey has typically been a matter of years for refugees and asylum seekers.

For second-generation immigrants residing in Germany, we generally observe a pattern of welfare dependence which is very close to that observed among native Germans. The marginal effects of the citizenship indicators demonstrate that, on average, they are relatively unlikely to be on welfare, although the differences to natives are small if significant at all. The age profile of second-generation migrants resembles that of natives, albeit with a somewhat more pronounced curvature. Among second-generation migrants residing in Germany, it is particularly problematic to command only low human capital endowments, while long-term joblessness has apparently not such a detrimental effect.

On balance, first- and second-generation immigrants display distinct patterns of dependence compared to natives but also compared to each other. The estimated marginal effects of the group indicators for the first generation suggest small but statistically significant lower probabilities to be observed as receiving social assistance. For example, being a firstgeneration Turkish immigrant reduces this probability by 0.82 percentage points all other factors equal. The comparable effects for the second generation are even smaller but for foreigners with Turkish, other guest worker country and other EU country citizenship they are statistically significantly negative.

To conclude, given the substantially lower education of foreigners as the major reason for their higher average (unconditional) rate of receiving welfare, their risk of being dependent on social assistance payments is conditional on observables by no means higher than that of comparable natives. If this pattern which our estimates reveal for existing migrants to Germany hold true for all future immigration, the message for immigration policy is clear and unmistakable: pursuing a deliberate and systematic immigration policy which balances human rights and the country's human capital requirements is the best option to assure that future immigrants will not become clients of the welfare system in any disproportionate fashion. 


\subsection{The Dependence of Immigrants on Public Transfer Payments - What Do People Think}

Often it is the case that a clear presentation of the stylized facts or of a convincing body of evidence is not able to prevent the public debate from going astray. The age-old fear that immigrants take jobs away from native workers is a case in point. Despite overwhelming evidence that the negative partial equilibrium effects on the most-affected groups of native workers are - at worst - minor and that they are probably overcompensated by the positive indirect effects, the argument of "native jobs first" is raised again and again by antiimmigrationists in all countries. Unfortunately, since this argument appeals to the strong underlying fear for one's own economic existence, and since it is easy to mask xenophobic attitudes behind such a seemingly well-justified concern, anti-immigrationists are often able to collect support for their - unjustified - claims.

Here, in the case of immigrant welfare dependence, defining an appropriate position is even more difficult, since there is an additional subtlety to consider. On average, it is true that immigrants to Germany are substantially more likely to be on welfare roles. Yet, as the preceding discussion has clearly demonstrated, this is a matter of key socio-economic characteristics, rather than a consequence of underlying unobservable traits. To the contrary, holding observables constant, immigrants are less likely to be on welfare. Thus, existing patterns are largely a result of past immigration policy, and future problems could be prevented by following a deliberate, and more skill-oriented immigration policy.

It seems safe to argue that the typical member of the indigenous German population is far removed from being aware of these subtleties. Thus, it would be extremely important to ascertain what exactly are the perceptions of native Germans regarding this important aspect of immigration and of immigration policy. Thus, after gauging possible gaps between facts and perceptions, and the correlates of such gaps, one could engage into considerations how to systematically remove such disparities. The assessment of perceptions is the topic of this subsection.

The empirical literature on the perception of immigrants and foreigners as well as the natives' attitudes towards them is quite scarce for Germany. Exceptions are GANG AND RIVERA-BATIZ (1994) using the Eurobarameter survey and BAUER ET AL. (2000) performing a cross-country comparison with the 1995 wave of the ISSP survey, which for the case of Germany, was conducted as an appendix to the ALLBUS (Allgemeine Bevölkerungsumfrage der Sozialwissenschaften). The latter paper focuses on the link between immigration policy and the perception of migrants. This paper, by contrast, contributes to the received literature 
by using the detailed information available in the ALLBUS to quantify the explanatory power of different individual variables for the perception of foreigners in Germany.

The ALLBUS is an publicly available opinion survey based on a representative sample of residents in Germany which is conducted biannually with varying focuses on different topics. The sample is drawn out of out of all individuals living in private households who, for the 1996 wave, have been born prior to January, $1^{\text {st }} 1978$. This wave, conducted between March and June 1996, contains questions on the perception of and attitudes towards immigrants and foreigners as well as standard socio-economic characteristics of the respondents. The majority of the respondents are German natives but there is also a representative share of foreigners in the sample.

\section{Attitudes of native respondents}

Overall, the respondents perceive immigrants - foreigners as well as ethnic Germans - and non-citizens living in Germany with a considerable degree of skepticism. Unfortunately, the questions on what is called "foreigner" in the ALLBUS are not distinguishing between foreign born and German born non-citizens, preventing us from extending the analysis to differences in the perception of first- and second-generation immigrants. However, some of the questions differentiate among immigrant groups, like Turks, Italians, ethnic Germans, and asylum seekers. The upper panel of Table 7 reports the distribution of agreement of native respondents in East and West Germany with three claims related to the impact of foreigners on the German housing and labor market, as well as on the propensity to convict crimes. Originally, there were seven categories of possible agreement/disagreement with these claims on an ordered scale reaching form (1) "I do not agree at all" to (7) "I agree completely". These seven possibilities were condensed into three categories: (1) and (2) into "no agreement", (6) and (7) into "agreement" and the other three original categories into "medium".

Table 7 reveals that approximately 32\% (28\%), 20\% (43\%), and 26\% (38\%) in West (East) Germany agreed with the respective claim, whereas around 23\% (28\%), 34\% (18\%), and $32 \%$ (20\%) did not. Natives in the western part of the country seem to be more concerned with the housing market impact of immigration than East Germans are, whereas the latter are more concerned with the labor market impact. Presumably as a consequence of this perception, the majority of respondents claimed that immigration should be limited and a substantial fraction even opted for a complete immigration stop. Table 8 reports the respective shares of answers. Somewhat surprising is the high share of respondents in Eastern 
Germany opting for an immigration stop of workers from EU-countries which is considerably larger than that concerning asylum seekers. One might speculate that this is due to the formulation "workers" in the question. Unfortunately, there is no control question with a more “innocuous" formulation.

The distribution of agreement with the claim "Foreigners should be sent back if unemployment is high" (Table 7) suggests that labor market worries might play a substantial role in explaining this distribution which are again more pronounced in East Germany. Moreover, the facts that around $30 \%$ of respondents in both parts of the country agreed with the claim that foreigners should be prohibited from political activity in Germany, that a substantial share would not agree with a full legal equivalency of different immigrant groups with native Germans, and that more than $43 \%$ of the native respondents claimed it would be important that German citizenship is connected to being of German descent (not reported in the tables), suggest that a substantial fraction of the German population is perceiving immigrants mainly as guests which are presumed to live in Germany only for a temporary period. On balance, immigrants from Italy which have on average a longer duration of residency in Germany and ethnic German migrants are perceived much more positively than Turks and especially asylum seekers. This pattern is reflected in the distribution of answers on the questions in the last two panels in Table 7.

From the perspective of our analysis in the preceding sub-section the distribution of agreement to the claim "Foreigners are a burden for the social security system in Germany" is of special interest. The distribution of agreement in the original seven categories, reported in Table 9 is quite uniform with a considerable share of respondents agreeing with this claim. For an analysis of the determining factors of the propensity to opt for different degrees of agreement we dropped the observations on respondents who refused to answer and condensed the remaining information into the three categories as explained above. This procedure provides us with an ordinal variable containing three categories of agreement which we use as the dependent variable in an ordered probit model in the next sub-section.

\subsection{Possible Explanations For the Divergence Between Facts and Perceptions}

The ordered probit model is a widely used model in a discrete choice framework with ordinal dependent variables. In such models it is assumed that respondents display a certain intensity of opinion which is an unobservable latent variable for the analyst, but can be explained by a set of measurable factors and an unobservable error term. Moreover, it is assumed that this unobservable intensity of opinion is reflected by the observable answers of the respondents, 
i.e. respondents choose the category which represents most closely their true opinion on the question. In the example at hand we have three categories and assume that the error term is normally distributed. The resulting ordered probit model can be estimated by Maximum Likelihood. The estimated coefficients for the explanatory variables are quite difficult to interpret directly since they are not equal to the marginal effects of the respective variable. However, these marginal effects, i.e. the change in the probability to choose a certain answer in response to a unit change in the regressors can be calculated from the coefficients and interpreted quite straightforwardly for the two extreme categories, albeit not for the middle category (cf. e.g. GREENE (1997)).

Table A.2 in the Appendix explains the set of explanatory variables which contains socioeconomic individual characteristics (like age, sex, education etc.), three self-classified attitude variables not related to foreigners, information on the respondents' partner and a measure of possible contacts to foreigners. Concerning the latter variable, more than half of the respondents in the 1996 wave of the ALLBUS report contact(s) to foreigners in either family, neighborhood, among friends or at work, but the intensity of these contacts remains unclear. Therefore, we decided to use a measure of exposure to foreigners, i.e. the actual share of foreigners living in the region (Landkreis) of the respondent to have an indicator for possible contacts to foreigners and, therefore, on the possible information of the respondent concerning foreigners. Table 10 reports some descriptive statistics of the variables in the sample.

\section{Estimation Results}

The estimated coefficients, associated t-values and marginal effects of our preferred specification are reported in Table 11. This specification is the result of several tests on equality restrictions on the parameters of the different categorized explanatory variables. The majority of the estimated coefficients is statistically significant at a 5\% significance level.

The observable tendency of agreement displays a u-shaped profile in age, due to the disproportionate share of young respondents displaying agreement. German citizens tend to agree much more emphatically with the proposed statement, as do women (a marginal increase of some 20 and 5 percentage points, respectively). Education is apparently a very important determinant of respondents' attitude to the issue, as it is particularly the low educated who agree with the proposed - and as we have seen completely unreflected statement.

The estimated marginal effects suggest that residing in Eastern Germany increases the probability to agree to the claim by nearly 10 percentage points. Somewhat surprisingly, after 
controlling for other covariates, the labor market variables "currently unemployed" and "fears loss of employment" have no statistically significant effect on the probability to opt for a certain opinion category. This result also holds if both variables are examined separately for East and West Germany. It has been argued above that voicing fears of job loss might be a vehicle for many to mask underlying, rather xenophobic motives for an anti-imigrationist position. Our results seem to corroborate this argument. Moreover, classifying oneself as having a right-wing attitude increases this probability by approximately 5 percentage points, whereas the opposite attitude reduces it by around 10 percentage points.

It is to be expected that the contact with immigrants reduces xenophobic misperceptions. Having a partner with a foreign citizenship at birth reduces the probability of agreement by around 10 percentage points. Living in a region with a low foreigner share increases the probability of agreement by more than 5 percentage points, whereas living in a region with a high foreigner share has no statistical significant impact on the chosen answer category. Sensitivity tests concerning the division of regions with a low foreigner share do not display any substantial impact on the estimation results. However, the latter variable has to be interpreted with caution, since it may be endogenous if foreigners decide to live in regions where natives have a more positive perception of them. Usually, the residential choice of individuals is determined by a complex set of factors, including family relations, friends, labor market opportunities and local amenities. It is possible that for foreigners the perception by natives may contribute to the local amenities of candidate locations of residence, but it seems to be only one element out of a set of several factors. Therefore, we would expect that the endogeneity of this variable is not severe.

\section{Conclusions}

This paper provided a snapshot portrait of the immigrant population currently residing in Germany, with a special emphasis on the distinction of first- and second-generation migrants. To this end we provided a detailed characterization of both immigrant generations by demographic and socio-economic characteristics. The paper also an in-depth review of the received economic literature, conceptualizing these analyses along the three principal avenues of migration research. The manuscript thus contributes to our understanding of the current state of knowledge regarding the immigrant population of Germany. Most importantly, it has become transparent that there are considerable differences between both immigrants and natives as well as among the different immigrant generations themselves. Nevertheless, this 
review also demonstrated that at the current juncture a substantial number of relevant research questions remains unresolved.

The paper proceeds to offer its own substantive contribution to this research, by addressing one of the most contentious issues in the current debate, the welfare dependence of migrants. We contrasted the findings on the determining factors of the moderate risk of migrants to depend on public assistance payments with the perception of immigrants by native Germans using two complementary datasets. Furthermore, we derived some evidence on important correlates of the deviations between facts and perceptions and discussed which explanatory factors might be responsible for this phenomenon.

The implications of our analyses are twofold. First, our results suggest that for the case of Germany we are still in need of generating more empirical evidence on some of the most important questions of migration research. Researchers will hardly be able to complete this task without access to additional, individual-based data material. In light of this topic's importance for the future of our society, it is hoped that any initiative to collect such data will be funded generously, and that policy makers and administrators alike will support such endeavor.

Furthermore, the empirical evidence on the divergence of the perception of immigrants by natives from what we really know suggests that comprehensive education programs and initiatives to ascertain that this evidence is becoming more transparent to the general public may provide the basis for a more realistic perception of what is a large, albeit heterogeneous population group in Germany. But the success of such activities is far from being guaranteed. To analyze whether and to what extent education is really able to resolve misperceptions and to reduce xenophobic attitudes will be one of the key challenges of this line of research. A comprehensive scientific evaluation of this question as well as the effectiveness of other integration programs is one of the signposts guiding our future directions of research. 


\section{References}

Altonji, Joseph G. and DAVID CARD (1991), The Effects of Immigration on the Labor Market Outcomes of Less-skilled Natives. In: ABOwD, JoHN M. and RICHARD B. FrEEMAN (EDS.), Immigration, Trade, and the Labor Market. Chicago and London: University of Chicago Press, 201-234.

BAKer, Michael and Dwayne Benjamin (1995), The Receipt of Transfer Payments by Immigrants to Canada. Journal of Human Resources, 30, 650-676.

BAUER, THOMAS K. (1998), Arbeitsmarkteffekte der Migration und Einwanderungspolitik: Eine Analyse für die Bundesrepublik Deutschland (Labor Market Effects of Migration and Migration Policy: An Analysis for Germany). Heidelberg: Physika.

Bauer, Thomas K., Magnus Lofstrom and Klaus F. Zimmermann (2000), Immigration Policy, Assimilation of Immigrants and Natives' Sentiments Towards Immigrants: Evidence From 12 OECD-Countries. Swedish Economic Policy (forthcoming).

Baumol, William J., Sue Anne Batey Blackman and EDward N. Wolff (1989), Productivity and the American Leadership: The Long View. Cambridge: MIT Press.

BERNINGHAUS AND SEIFERT-Vogt (1991), International Migration under Incomplete Information. Berlin: Springer-Verlag.

BIEWEN, MARTIN (2000), Contributions to the Measurement of German Income Inequality. Ph.D. Thesis, University of Heidelberg.

BlaU, Francine D. (1984), The Use of Transfer Payments by Immigrants. Industrial and Labor Relations Review, 37, 222-239.

Blundell, Richard, VANESSA Fry and IAN WALKER (1988), Modelling the Take-Up of Means-Tested Benefits: The Case of Housing Benefits in the United Kingdom. Economic Journal, 98, 58-74.

BorJAs, GeOrge J. (1985), Assimilation, Changes in Cohort Quality, and the Earnings of Immigrants. Journal of Labor Economics, 3, 463-489.

Borjas, GeOrge J. (1987), Self-Selection and the Earnings of Immigrants. American Economic Review, 77, 531-553.

BorJas, GeORGE J. (1991), Immigration and Self-Selection. In: ABOWD, JOHN M. and

RichARD B. FREEMAN (EDS.), Immigration, Trade, and the Labor Market. Chicago and London: University of Chicago Press, 29-76.

Borjas, GeOrge J. (1999), Heaven's Door: Immigration Policy and the American Economy. Princeton: Princeton University Press. 
Borjas, George J. and StePhen P. TRejo (1991), Immigrant Participation in the Welfare System. Industrial and Labor Relations Review, 44, 195-211.

BorJAs, GEORGE J. and StePHEN P. TREJo (1993), National Origin and Immigrant Welfare Recipiency. Journal of Public Economics, 50, 325-344.

Borjas, George J. and Lynette Hilton (1996), Immigration and the Welfare State: Immigrant Participation in Means-Tested Entitlement Programs. Quarterly Journal of Economics, 111, 575-604.

CARD, DAvid (1990), The Impact of the Mariel Boatlift on the Miami Labor Market. Industrial and Labor Relations Review, 43, 245-57.

CARLIn, WEndy (1996), West German Growth and Institutions, 1945-1990. In: CRAFTS, Nicholas and Gianni Toniolo (EDS.), Economic Growth in Europe since 1945. Cambridge: Cambridge University Press.

CHISWICK, BARRY R. (1978), The Effect of Americanization on the Earnings of ForeignBorn Men. Journal of Political Economy, 86, 897-921.

DeNew, John and Klaus F. Zimmermann (1994), Native Wage Impacts of Foreign Labor: A Random Effects Panel Analysis. Journal of Population Economics, 7, 177-192.

Dustmann, Christian (1993), Earnings Adjustments of Temporary Migrants. Journal of Population Economics, 6, 153-168.

Dustmann, Christian (1996), Return Migration: The European Experience. Economic Policy, 22, 213-242.

Dustmann, Christian and IAN Preston (2000), Racial and Economic Factors in Attitudes to Immigration, IZA Discussion Paper No. 190.

Dustmann, Christian and Christoph M. Schmidt (2000), The Wage Performance of Immigrant Women: Full-Time Jobs, Part-Time Jobs, and the Role of Selection. IZA Discussion Paper No. 233.

FERTIG, Michael (1999), The Economic Impact of EU-Enlargement: Assessing the Migration Potential. Empirical Economics (forthcoming).

Fertig, Michael and Christoph M. SCHMIDT (2000), Aggregate Level Migration Studies as a Tool for Forecasting Future Migration Streams. In: DJAJIC, SlobODAN (ED.), International Migration: Trends, Policy and Economic Impact (forthcoming). London: Routledge.

FiLER, RANDALL K. (1992), The Effect of Immigrant Arrivals on Migratory Patterns of Native Workers. In: BorJAS, GEORGE J. and RICHARD B. FREEMAN (EDS.), Immigration and 
the Work Force: Economic Consequences for the United States and Source Areas. Chicago: University of Chicago Press.

GANG, IRA N. and F. L. RiverA-BATIZ (1994), Unemployment and Attitudes Towards Foreigners in Germany. In: SteInMANN, G. and R.E. UlRICH (EDS.), The Economic Consequences of Immigration to Germany, Heidelberg: Physica-Verlag, 121-154.

Greene, William H. (1997), Econometric Analysis. $3^{\text {rd }}$ edition, London: Prentice Hall International.

Haisken-DeNew, John P. (1996), Migration and the Inter-Industry Wage Structure in Germany, Heidelberg/New York: Springer Verlag.

HARris, J. R. and TODARO, Michael P. (1970), Migration, Unemployment and Development: A Two-Sector Analysis. American Economic Review, 60, 126-142.

HunT, JENNIFER (1992), The Impact of the 1962 Repatriates from Algeria on the French Labor Market. Industrial and Labor Relations Review, 45, 556-572.

LaLonde, Robert J. and Robert H. TOPEL (1991), Labor Market Adjustments to Increased Immigration. In: ABOWD, JOHN M. and RICHARD B. FREEMAN (EDS.), Immigration, Trade, and the Labor Market. Chicago and London: University of Chicago Press, 167-199.

LALONDE, ROBERT J. and ROBERT H. TOPEL (1992), The Assimilation of Immigrants in the U.S. Labor Market. In: BORJAS, GEORGE J.and RichARD B. FREEMAN (EDS.), Immigration and the Work Force. Chicago and London: University of Chicago Press, 67-92.

LALONDE, RoBert J. and Robert H. TOPEL (1997), Economic Impact of International Migration and the Economic Performance of Migrants. In: RosEnZWEIG, MARK R. and ODED STARK (EDS.), Handbook of Population and Family Economics (Handbooks in Economics, vol. 14.) Amsterdam, New York and Oxford: Elsevier Science, North-Holland, 799-850.

PischKe, JÖRN-STEFFEN and JOHANNES VELLING (1997), Employment Effects of Immigration to Germany: An Analysis Based on Local Labor Markets. Review of Economics \& Statistics. 79, 594-604.

RIPHAHN, REgina T. (2000), Dissimilation? The Educational Attainment of Second Generation Immigrants. mimeo., University of Munich.

RiPHAHN, ReginA T. (1998), Immigrant Participation in the German Welfare Program. Finanzarchiv, 55, 163-185.

SCHMIDT, Christoph M. (1994), Country of Origin, Family Structure and Return Migration. Vierteljahreshefte zur Wirtschaftsforschung, 63, 119-125. 
SCHMIDT, Christoph M. (1996), German Economic Growth After the Demise of Socialism: The Potential Contribution of East-West Migration. Jahrbuch für Wirtschaftsgeschichte, 1996/2, 109-126.

SCHMIDT, CHRISTOPH M. (1997), Immigrant Performance in Germany: Labor Earnings of Ethnic German Migrants and Foreign Guest-Workers. The Quarterly Review of Economics and Finance, 37, 379-397.

SCHMidT, Christoph M. (1999), Knowing What Works - The Case For Rigorous Program Evaluation. IZA Discussion Paper No. 77.

SCHMIDT, Christoph M. (2000), Reconstructing Germany: The Demographic Impact of Immigration During the Post-War Era. mimeo., University of Heidelberg.

Schmidt, Christoph M. and Klaus F. Zimmermann (1992), Migration Pressure in Germany: Past and Future. In: Zimmermann, Klaus F. (ED.): Migration and Economic Development. Berlin: Springer, 207-236.

Schmidt, Christoph M., Stiltz, Anette and Klaus F. Zimmermann (1994), Mass Migration, Unions, and Government Intervention. Journal of Public Economics, 55, 185-201.

STARK, OdED (1991), The Migration of Labor. Cambridge: Basil Blackwell.

Vogler, Michael and RalPH RotTe (2001), The Effects of Development on Migration: Theoretical Issues and New Empirical Evidence. Journal of Population Economics, 13, 485508.

YuEngERT, A. M. (1994), Immigrant Earnings Relative to What ? The Importance of Earnings Function Specification and Comparison Points. Journal of Applied Econometrics, 9, 71-90.

Die in diesem Beitrag benutzten Daten entstammen der "Allgemeinen Bevölkerungsumfrage der Sozialwissenschaften" (ALLBUS). Der ALLBUS 1996 ist eine von Bund und Ländern über die GESIS (Gesellschaft sozialwissenschaftlicher Infrastruktureinrichtungen) finanzierte Umfrage, die vom ZUMA (Zentrum für Umfragen, Methoden und Analysen, Mannheim) und vom Zentralarchiv für Empirische Sozialforschung (Köln) in Zusammenarbeit mit dem ALLBUS-Ausschuß realisiert wurde. Die Dokumentationen und Daten sind beim Zentralarchiv für Empirische Sozialforschung (Köln) erhältlich. Die vorgenannten Institutionen und Personen tragen keine Verantwortung für die Verwendung der Daten in diesem Beitrag. 
Table 1: The Distribution of Immigrants and Natives by Federal State and Citizenship

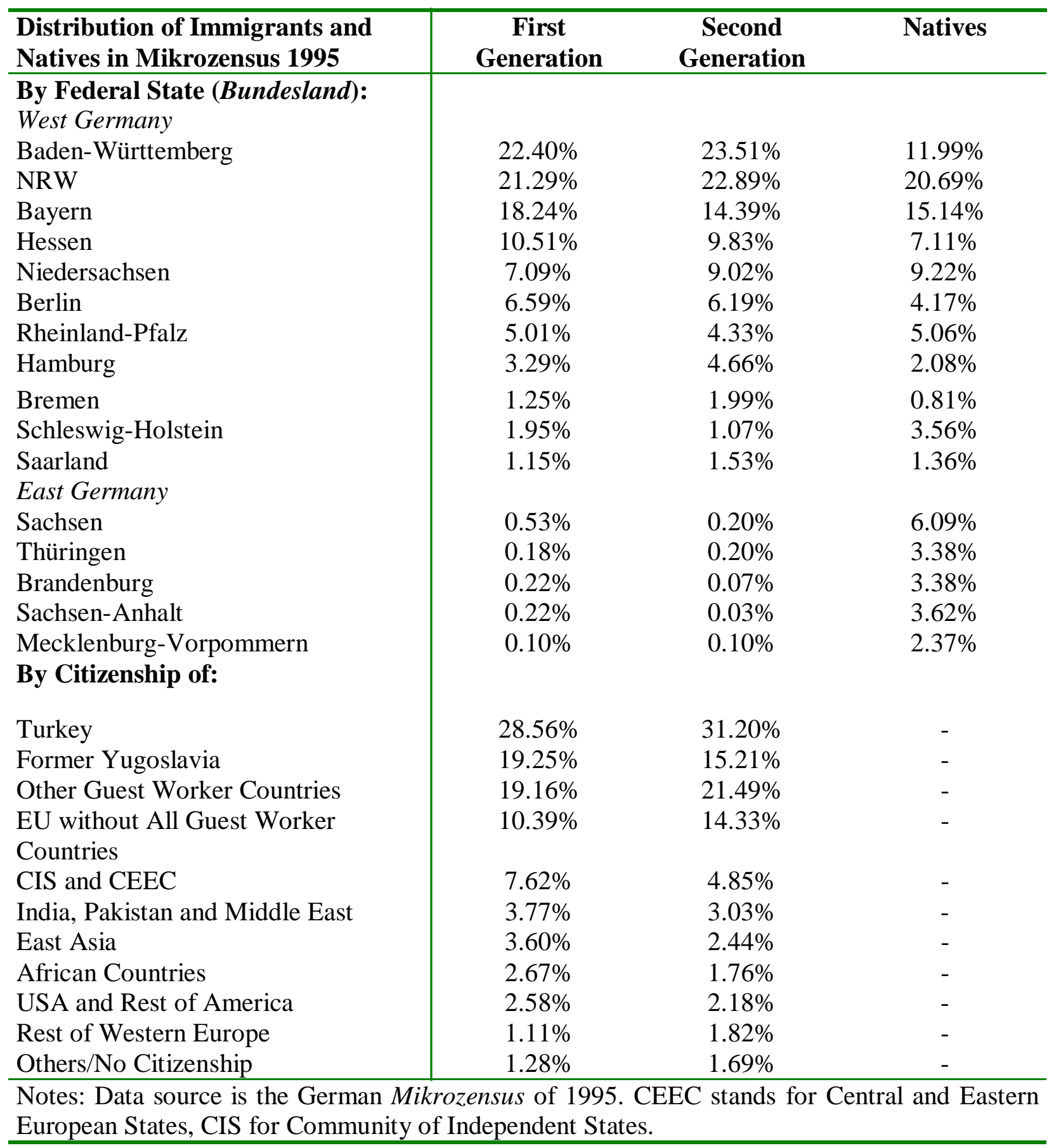


Table 2: The Education of Immigrants and Natives

\begin{tabular}{l|ccc}
\hline Education Levels & $\begin{array}{c}\text { First } \\
\text { Generation }\end{array}$ & $\begin{array}{c}\text { Second } \\
\text { Generation }\end{array}$ & $\begin{array}{c}\text { Native } \\
\text { Germans }\end{array}$ \\
\hline Highest Schooling Degree: & $21.22 \%$ & $22.10 \%$ & $5.73 \%$ \\
Other & $49.00 \%$ & $47.04 \%$ & $49.80 \%$ \\
Elementary Schooling & $12.71 \%$ & $16.87 \%$ & $27.20 \%$ \\
Advanced Schooling & $17.06 \%$ & $13.99 \%$ & $17.27 \%$ \\
Higher Schooling & & & \\
Formal Training level: & $8.26 \%$ & $16.95 \%$ & $5.54 \%$ \\
Other & $45.68 \%$ & $35.31 \%$ & $19.22 \%$ \\
None & $8.42 \%$ & $5.76 \%$ & $10.87 \%$ \\
(Technical) University Degree & $34.65 \%$ & $39.30 \%$ & $55.48 \%$ \\
Vocational Training & $2.99 \%$ & $2.68 \%$ & $8.88 \%$ \\
Advanced Vocational Training & \multicolumn{3}{l}{. } \\
\hline Notes: Data source is the German Mikrozensus of 1995. The highest schooling degree is \\
reported for all individuals older than 15 years. The highest formal training level is reported \\
for all individuals older than 18 years.
\end{tabular}

Table 3: Sectoral Distribution of Immigrants and Natives

\begin{tabular}{l|ccc}
\hline & $\begin{array}{c}\text { First } \\
\text { Generation }\end{array}$ & $\begin{array}{c}\text { Second } \\
\text { Generation }\end{array}$ & Natives \\
\hline Unemployment Rate & $11.09 \%$ & $7.65 \%$ & $6.09 \%$ \\
Size of Labor Force & 19,566 & 4,613 & 329,112 \\
Share of Population in Germany & $4.38 \%$ & $1.89 \%$ & $93.73 \%$ \\
Share of Labor Force in Selected & & & \\
Sectors: & & & \\
Manufacturing & $30.18 \%$ & $21.24 \%$ & $23.37 \%$ \\
Construction Sector & $8.17 \%$ & $5.79 \%$ & $8.38 \%$ \\
Food and Beverages & $7.16 \%$ & $4.96 \%$ & $2.22 \%$ \\
Banking and Insurance & $0.91 \%$ & $1.34 \%$ & $3.18 \%$ \\
Total: & $\mathbf{4 6 . 4 2 \%}$ & $\mathbf{3 3 . 3 4 \%}$ & $\mathbf{3 7 . 1 5 \%}$ \\
& & & \\
Share of All Employed in Selected & & & $24.89 \%$ \\
Sectors: & & & $8.92 \%$ \\
Manufacturing & $33.94 \%$ & $23.00 \%$ & $2.36 \%$ \\
Construction Sector & $9.19 \%$ & $6.27 \%$ & $3.38 \%$ \\
Food and Beverages & $8.05 \%$ & $5.38 \%$ & $\mathbf{3 9 . 5 6 \%}$ \\
Banking and Insurance & $1.03 \%$ & $1.46 \%$ & \\
Total: & $\mathbf{5 2 . 2 1 \%}$ & $\mathbf{3 6 . 1 0 \%}$ & The labor force \\
\hline Notes: Data source is the German all \\
individuals aged 15 to 65 years.
\end{tabular}


Table 4: Primary Sources of Income for Living

\begin{tabular}{|c|c|c|c|}
\hline Primary Income Source & $\begin{array}{c}\text { First } \\
\text { Generation }\end{array}$ & $\begin{array}{c}\text { Second } \\
\text { Generation }\end{array}$ & $\begin{array}{l}\text { Native } \\
\text { Germans }\end{array}$ \\
\hline Work Income & $64.84 \%$ & $62.42 \%$ & $55.89 \%$ \\
\hline $\begin{array}{l}\text { Unemployment Benefit and Assistance } \\
\text { Payments }\end{array}$ & $7.05 \%$ & $5.31 \%$ & $4.11 \%$ \\
\hline Pensions & $7.41 \%$ & $7.13 \%$ & $28.56 \%$ \\
\hline Support by Parents or Spouse & $7.31 \%$ & $9.93 \%$ & $6.84 \%$ \\
\hline Other (Non-Work) Income & $0.38 \%$ & $0.42 \%$ & $0.43 \%$ \\
\hline Social Assistance Program & $11.36 \%$ & $12.8 \%$ & $1.76 \%$ \\
\hline Other Benefits (Student Grants etc.) & $1.66 \%$ & $1.99 \%$ & $2.40 \%$ \\
\hline
\end{tabular}




\begin{tabular}{|c|c|c|}
\hline & Mean & Standarderror \\
\hline Dependence on Social Assistance & 0.018 & 0.134 \\
\hline \multicolumn{3}{|l|}{ Household Characteristics: } \\
\hline Married & 0.680 & 0.466 \\
\hline Single with Child(ren) & 0.068 & 0.253 \\
\hline Number of Children & 0.496 & 0.850 \\
\hline Residing in East Germany & 0.182 & 0.386 \\
\hline \multicolumn{3}{|l|}{ Individual Characteristics: } \\
\hline Age & 42.531 & 12.741 \\
\hline Female & 0.503 & 0.500 \\
\hline High Education & 0.172 & 0.377 \\
\hline Low Education & 0.538 & 0.499 \\
\hline (Technical) University Degree & 0.115 & 0.320 \\
\hline No Formal Training & 0.229 & 0.420 \\
\hline Part-Time Work & 0.107 & 0.310 \\
\hline Temporary Work Contract & 0.049 & 0.216 \\
\hline Employed in Public Sector & 0.199 & 0.400 \\
\hline Minor Employment & 0.028 & 0.165 \\
\hline Not Employed & 0.072 & 0.259 \\
\hline Not Employed For More Than Six Months & 0.060 & 0.237 \\
\hline \multicolumn{3}{|l|}{ Information Level Indicators: } \\
\hline Inhabitant of a Small City (less than 20,000) & 0.421 & 0.494 \\
\hline Inhabitant of a Big City (more than 100,000) & 0.298 & 0.458 \\
\hline \multicolumn{3}{|l|}{ First-Generation Characteristics: } \\
\hline Turkish Nationality & 0.019 & 0.135 \\
\hline Yugoslavian Nationality & 0.011 & 0.103 \\
\hline Other Guest Worker Country Nationality & 0.011 & 0.102 \\
\hline Other EU-Country Nationality & 0.005 & 0.070 \\
\hline CIS or CEEC Nationality & 0.005 & 0.068 \\
\hline Other Nationality & 0.009 & 0.093 \\
\hline Age & 2.245 & 9.476 \\
\hline High Education & 0.009 & 0.094 \\
\hline Low Education & 0.042 & 0.202 \\
\hline Not Employed & 0.007 & 0.083 \\
\hline Not Employed For More Than Six Months & 0.005 & 0.073 \\
\hline High Education in Origin Country & 0.005 & 0.070 \\
\hline Low Education in Origin Country & 0.036 & 0.186 \\
\hline Duration of Residence in Germany & 0.892 & 4.360 \\
\hline
\end{tabular}




\begin{tabular}{l|cr}
\hline & Mean & Standarderror \\
\hline Second-Generation Characteristics: & 0.003 & 0.056 \\
Turkish Nationality & 0.001 & 0.038 \\
Yugoslavian Nationality & 0.002 & 0.047 \\
Other Guest Worker Country Nationality & 0.001 & 0.037 \\
Other EU-Country Nationality & 0.001 & 0.022 \\
CIS or CEEC Nationality & 0.001 & 0.037 \\
Other Nationality & 0.331 & 3.525 \\
Age & 0.001 & 0.035 \\
High Education & 0.007 & 0.085 \\
Low Education & 0.001 & 0.033 \\
Not Employed & 0.001 & 0.026 \\
Not Employed For More Than Six Months & & \\
\hline Notes: Means and standard error
\end{tabular}

Notes: Means and standard errors are for the complete sample. Number of observations: 305,962. See Table A.1 and the text for a description of the variables. 


\begin{tabular}{|c|c|c|}
\hline & Marginal Effect & t-Value \\
\hline \multicolumn{3}{|l|}{ Household Characteristics: } \\
\hline Married & -0.1081 & -36.37 \\
\hline Single with Child(ren) & 0.0102 & 25.25 \\
\hline Number of Children & 0.0026 & 27.65 \\
\hline Residing in East Germany & -0.0033 & -14.21 \\
\hline \multicolumn{3}{|l|}{ Individual Characteristics: } \\
\hline Age and Age Squared & -0.0001 & -10.45 \\
\hline Female & 0.0008 & 4.72 \\
\hline High Education & -0.0018 & -4.73 \\
\hline Low Education & 0.0026 & 10.72 \\
\hline (Technical) University Degree & 0.0012 & 2.23 \\
\hline No Formal Training & 0.0114 & 38.18 \\
\hline Part-Time Work & -0.0038 & -13.50 \\
\hline Temporary Work Contract & -0.0041 & -13.79 \\
\hline Employed in Public Sector & -0.0026 & -11.14 \\
\hline Minor Employment & 0.0049 & 6.03 \\
\hline Not Employed & 0.0161 & 24.34 \\
\hline Not Employed For More Than Six Months & 0.0060 & 11.91 \\
\hline \multicolumn{3}{|l|}{ Information Level Indicators: } \\
\hline Inhabitant of a Small City (less than 20,000) & -0.0013 & -6.40 \\
\hline Inhabitant of a Big City (more than 100,000) & 0.0018 & 8.04 \\
\hline \multicolumn{3}{|l|}{ Foreigner Characteristics: } \\
\hline High Education & 0.0003 & 0.32 \\
\hline Not Employed & -0.0005 & -0.81 \\
\hline \multicolumn{3}{|l|}{ First-Generation Characteristics: } \\
\hline Turkish Nationality & -0.0082 & -19.04 \\
\hline Yugoslavian Nationality & -0.0060 & -18.18 \\
\hline Other Guest Worker Country Nationality & -0.0062 & -19.55 \\
\hline Other EU-Country Nationality & -0.0049 & -19.43 \\
\hline CIS or CEEC Nationality & -0.0048 & -18.29 \\
\hline Other Nationality & -0.0056 & -18.34 \\
\hline Age and Age Squared & -0.0004 & -3.28 \\
\hline Low Education & 0.0005 & 0.42 \\
\hline Not Employed For More Than Six Months & 0.0019 & 2.13 \\
\hline Low Education in Origin Country & -0.0023 & -3.23 \\
\hline $\begin{array}{l}\text { Duration of Residence in Germany and Duration of } \\
\text { Residence in Germany Squared }\end{array}$ & -0.0016 & -17.77 \\
\hline
\end{tabular}


Table 6 continued: Estimation Results of Probit Model - Mikrozensus 1995

\begin{tabular}{l|rr}
\hline & Marginal Effect & t-Value \\
\hline Second-Generation Characteristics: & & -2.75 \\
Turkish Nationality & -0.0040 & -0.49 \\
Yugoslavian Nationality & -0.0018 & -3.62 \\
Other Guest Worker Country Nationality & -0.0040 & -3.51 \\
Other EU-Country Nationality & -0.0040 & -0.49 \\
CIS or CEEC Nationality & -0.0019 & 0.40 \\
Other Nationality & 0.0024 & 1.91 \\
Age and Age Squared & 0.0005 & 4.33 \\
Low Education & 0.0152 & -4.26 \\
Not Employed For More Than Six Months & -0.0034 & \\
Diagnostics: & & \\
Homogeneity of First-Generation Foreigner Groups & $256.98(15.09)$ \\
Homogeneity of Sec.-Generation Foreigner Groups & $234.57(15.09)$ \\
Homogeneity of First- and Second-Generation & $298.98(16.81)$ & \\
Homogeneity of Natives and First-Generation & $678.49(16.81)$ & \\
Homogeneity of Natives and Second-Generation & $241.61(16.81)$ \\
\hline Notes: Number of observations 305,962. Numbers in parentheses are the critical values of the \\
$\chi^{2}$ (5) and $\chi^{2}$ (6) at the 1\% confidence level. & & \\
\hline
\end{tabular}


Table 7: Attitudes Towards Foreigners - ALLBUS 1996

\begin{tabular}{|c|c|c|c|c|c|c|}
\hline \multirow[t]{2}{*}{ Claim or Question } & \multicolumn{2}{|c|}{ No Agreement } & \multicolumn{2}{|c|}{ Medium } & \multicolumn{2}{|c|}{ Agreement } \\
\hline & West & East & West & East & West & East \\
\hline $\begin{array}{l}\text { Foreigners are a burden for the } \\
\text { housing market. }\end{array}$ & $23.04 \%$ & $27.97 \%$ & $44.84 \%$ & $43.78 \%$ & $32.12 \%$ & $28.25 \%$ \\
\hline Foreigners take jobs away. & $34.34 \%$ & $18.28 \%$ & $45.67 \%$ & $38.55 \%$ & $19.99 \%$ & $43.17 \%$ \\
\hline Foreigners commit more crimes. & $31.70 \%$ & $19.71 \%$ & $42.32 \%$ & $42.60 \%$ & $25.89 \%$ & $37.69 \%$ \\
\hline $\begin{array}{l}\text { Foreigners should be sent back if } \\
\text { unemployment is high. }\end{array}$ & $42.04 \%$ & $26.18 \%$ & $40.52 \%$ & $42.75 \%$ & $17.43 \%$ & $31.07 \%$ \\
\hline $\begin{array}{l}\text { Foreigners should be prohibited } \\
\text { from political activity in Germany. }\end{array}$ & $35.61 \%$ & $33.30 \%$ & $36.48 \%$ & $37.11 \%$ & $27.90 \%$ & $29.58 \%$ \\
\hline $\begin{array}{l}\text { Full Legal Equivalency to Native } \\
\text { Germans For: }\end{array}$ & & & & & & \\
\hline Italians & $16.14 \%$ & $17.83 \%$ & $44.03 \%$ & $48.33 \%$ & $39.83 \%$ & $33.85 \%$ \\
\hline Ethnic Germans & $14.43 \%$ & $16.21 \%$ & $41.40 \%$ & $47.19 \%$ & $44.17 \%$ & $36.59 \%$ \\
\hline Asylum Seekers & $52.40 \%$ & $42.66 \%$ & $36.85 \%$ & $42.93 \%$ & $10.75 \%$ & $14.40 \%$ \\
\hline Turks & $31.10 \%$ & $29.56 \%$ & $46.01 \%$ & $46.24 \%$ & $22.89 \%$ & $24.21 \%$ \\
\hline $\begin{array}{l}\text { Would You Appreciate Living in } \\
\text { the Neighborhood of ... ? }\end{array}$ & $\begin{array}{r}\mathrm{N} \\
\text { Appr }\end{array}$ & $\begin{array}{l}\text { ot } \\
\text { eciate }\end{array}$ & Med & ium & Appr & ciate \\
\hline Italians & $2.38 \%$ & $7.15 \%$ & $61.44 \%$ & $74.75 \%$ & $36.18 \%$ & $18.10 \%$ \\
\hline Ethnic Germans & $7.12 \%$ & $9.33 \%$ & $68.44 \%$ & $74.37 \%$ & $24.44 \%$ & $16.30 \%$ \\
\hline Asylum Seekers & $31.69 \%$ & $31.16 \%$ & $58.93 \%$ & $63.68 \%$ & $9.37 \%$ & $5.16 \%$ \\
\hline Turks & $17.15 \%$ & $27.26 \%$ & $68.00 \%$ & $65.67 \%$ & $14.86 \%$ & $7.07 \%$ \\
\hline $\begin{array}{l}\text { Would You Appreciate it if a ... } \\
\text { Marries a Member of Your } \\
\text { Family? }\end{array}$ & $\begin{array}{r}\mathrm{N} \\
\text { Appr }\end{array}$ & $\begin{array}{l}\text { ot } \\
\text { eciate }\end{array}$ & Med & ium & Appr & ciate \\
\hline Italian & $7.89 \%$ & $17.98 \%$ & $67.37 \%$ & $71.21 \%$ & $24.74 \%$ & $10.81 \%$ \\
\hline Ethnic German & $12.72 \%$ & $18.26 \%$ & $69.79 \%$ & $73.02 \%$ & $17.49 \%$ & $8.72 \%$ \\
\hline Asylum Seeker & $45.59 \%$ & $42.91 \%$ & $47.70 \%$ & $53.45 \%$ & $6.71 \%$ & $3.64 \%$ \\
\hline Turks & $37.56 \%$ & $42.09 \%$ & $53.31 \%$ & $54.09 \%$ & $9.14 \%$ & $3.82 \%$ \\
\hline
\end{tabular}

Notes: All figures are the respective shares of total valid answers of German citizens, i.e. without respondents who did not answer. The share of valid answers varies between $95.1 \%$ and $99.9 \%$. 
Table 8: Attitudes Towards Immigrants - ALLBUS 1996

\begin{tabular}{l|cccccc}
\hline $\begin{array}{l}\text { Immigration of Different } \\
\text { Groups }\end{array}$ & \multicolumn{2}{c}{ Unlimited Access } & Limited Access & \multicolumn{2}{c}{ No Access } \\
\cline { 2 - 7 } & West & East & West & East & West & East \\
\hline Ethnic German Migrants & $14.69 \%$ & $13.33 \%$ & $73.73 \%$ & $68.93 \%$ & $11.58 \%$ & $17.74 \%$ \\
Asylum Seekers & $12.68 \%$ & $11.55 \%$ & $65.74 \%$ & $67.47 \%$ & $21.58 \%$ & $20.98 \%$ \\
Workers From EU Countries & $32.98 \%$ & $11.11 \%$ & $54.95 \%$ & $50.98 \%$ & $12.07 \%$ & $37.91 \%$ \\
& $8.34 \%$ & $4.27 \%$ & $59.26 \%$ & $46.25 \%$ & $32.40 \%$ & $49.48 \%$ \\
$\begin{array}{l}\text { Workers From Non-EU } \\
\text { Countries }\end{array}$ \\
$\begin{array}{l}\text { Notes: All figures are the respective shares of total valid answers. The share of valid answers } \\
\text { varies between 95\% and 99.9\%. }\end{array}$
\end{tabular}

Table 9: Distribution of Agreement - ALLBUS 1996

\begin{tabular}{|c|c|c|}
\hline $\begin{array}{l}\text { Foreigners are a Burden for the } \\
\text { Social Security System }\end{array}$ & All Respondents & $\begin{array}{c}\text { Native Respondents } \\
\text { Only } \\
\end{array}$ \\
\hline No agreement at all & $13.43 \%$ & $12.14 \%$ \\
\hline Disagreement & $11.75 \%$ & $11.41 \%$ \\
\hline Mild disagreement & $12.35 \%$ & $12.17 \%$ \\
\hline Indifference & $20.78 \%$ & $20.65 \%$ \\
\hline Mild agreement & $14.23 \%$ & $14.90 \%$ \\
\hline Agreement & $11.55 \%$ & $12.10 \%$ \\
\hline Full agreement & $15.92 \%$ & $16.64 \%$ \\
\hline
\end{tabular}


Table 10: Summary Statistics - ALLBUS 1996

\begin{tabular}{l|cc}
\hline Variable & Mean & Standarderror \\
\hline Dependent Variable (coded: 0;1;2) & 1.023 & 0.725 \\
Individual Characteristics: & & 16.765 \\
Age & 46.070 & 0.238 \\
German Citizen & 0.940 & 0.465 \\
Residing in East Germany & 0.317 & 0.500 \\
Female & 0.506 & 0.367 \\
Living in a Single Household & 0.160 & 0.413 \\
High Degree of Schooling & 0.217 & 0.456 \\
Middle Degree of Schooling & 0.296 & 0.169 \\
Currently Unemployed & 0.029 & 0.328 \\
Employed in Public Sector & 0.123 & 0.083 \\
Currently in School & 0.007 & \\
Self-Classified Variables: & & 0.291 \\
Right Wing & 0.093 & 0.377 \\
Left Wing & 0.171 & 0.317 \\
Fears Loss of Employment & 0.113 & \\
Partner-Specific Variables: & & 0.491 \\
Partner is German Citizen & 0.597 & 0.136 \\
Partner has been Non-Citizen at Birth & 0.019 & 0.486 \\
Proximity Measure: & & 0.203 \\
Low Share of Foreigners & 0.617 & \\
High Share of Foreigners & & \\
\hline Notes: Number observations & & \\
\hline
\end{tabular}

Notes: Number of Observations is 3499. All figures are unweighted sample means and standarderrors, respectively. 
Table 11: Estimation Results of Ordered Probit Model - ALLBUS 1996

\begin{tabular}{|c|c|c|c|c|}
\hline \multirow{2}{*}{$\begin{array}{l}\text { Statement: "Foreigners are a } \\
\text { burden for the social security } \\
\text { system." }\end{array}$} & \multirow[t]{2}{*}{ Coefficient } & \multirow[t]{2}{*}{ t-Value } & \multicolumn{2}{|c|}{ Marginal Effects } \\
\hline & & & $\begin{array}{r}\operatorname{Pr}(Y=1) \\
\text { No agreement }\end{array}$ & $\begin{array}{r}\operatorname{Pr}(Y=3) \\
\text { agreement }\end{array}$ \\
\hline \multicolumn{5}{|l|}{ Individual Characteristics: } \\
\hline Age $\times 100$ & -0.078 & -2.14 & 0.020 & -0.030 \\
\hline Age Squared $\times 100$ & 0.007 & 4.49 & - & - \\
\hline German Citizen & 0.645 & 7.29 & -0.198 & 0.208 \\
\hline Residing in East Germany & 0.303 & 5.91 & -0.093 & 0.098 \\
\hline Female & 0.160 & 4.11 & -0.049 & 0.052 \\
\hline Living in a Single Household & 0.034 & 0.50 & -0.010 & 0.011 \\
\hline High Degree of Schooling & -0.439 & -8.03 & 0.135 & -0.142 \\
\hline Middle Degree of Schooling & -0.187 & -3.94 & 0.057 & -0.060 \\
\hline Currently Unemployed & -0.024 & -0.22 & 0.007 & -0.008 \\
\hline Employed in Public Sector & -0.200 & -3.26 & 0.061 & -0.065 \\
\hline Currently in School & -0.323 & -0.90 & 0.100 & -0.104 \\
\hline \multicolumn{5}{|l|}{ Self-Classified Variables: } \\
\hline Right Wing & 0.153 & 2.36 & -0.047 & 0.049 \\
\hline Left Wing & -0.304 & -5.99 & 0.093 & -0.098 \\
\hline Fears Loss of Employment & 0.097 & 1.55 & -0.030 & 0.031 \\
\hline \multicolumn{5}{|l|}{ Partner-Specific Variables: } \\
\hline Partner is German Citizen & 0.013 & 0.25 & -0.004 & 0.004 \\
\hline Partner has been Non-Citizen at & -0.320 & -2.10 & 0.100 & -0.103 \\
\hline \multicolumn{5}{|l|}{ Birth } \\
\hline \multicolumn{5}{|l|}{ Proximity Measure: } \\
\hline Low Share of Foreigners & 0.159 & 3.25 & -0.049 & 0.051 \\
\hline High Share of Foreigners & -0.058 & -0.54 & 0.018 & 0.019 \\
\hline
\end{tabular}


Table A.1: Variable Description - Mikrozensus 1995

\begin{tabular}{|c|c|}
\hline Variablename & Description \\
\hline Dependent Variable & $\begin{array}{l}1 \text { if individual reports social assistance payments as } \\
\text { main source of income for living; } 0 \text { otherwise }\end{array}$ \\
\hline \multicolumn{2}{|l|}{ Household Characteristics: } \\
\hline Married & 1 if individual is married; 0 otherwise \\
\hline Single with Child(ren) & $\begin{array}{l}1 \text { if household head is single with one or more children; } \\
0 \text { otherwise }\end{array}$ \\
\hline Number of Children & Absolute number of children in household \\
\hline Residing in East Germany & $\begin{array}{l}1 \text { if household resides in East Germany; } \\
0 \text { otherwise }\end{array}$ \\
\hline \multicolumn{2}{|l|}{ Individual Characteristics: } \\
\hline Age & Age of the individual in years $(15-65$ years $)$ \\
\hline Female & 1 if the individual is female; 0 otherwise \\
\hline High Education & $\begin{array}{l}1 \text { if the individual has a high schooling degree } \\
\text { (Hochschul- or Fachhochschulreife); } 0 \text { otherwise }\end{array}$ \\
\hline Low Education & $\begin{array}{l}1 \text { if the individual has no or a low (Hauptschule) } \\
\text { schooling degree; } 0 \text { otherwise }\end{array}$ \\
\hline (Technical) University Degree & $\begin{array}{l}1 \text { if the individual has a (technical) university degree; } 0 \\
\text { otherwise }\end{array}$ \\
\hline No Formal Training & 1 if the individual has no formal training; 0 otherwise \\
\hline Part-Time Work & Equals 1 if the individual works part-time; 0 otherwise \\
\hline Temporary Work Contract & $\begin{array}{l}1 \text { if the individual has a temporary work contract; } 0 \\
\text { otherwise }\end{array}$ \\
\hline Employed in Public Sector & $\begin{array}{l}1 \text { if the individual is employed in the public sector; } 0 \\
\text { otherwise }\end{array}$ \\
\hline Minor Employment & $\begin{array}{l}\text { Equals } 1 \text { if the individual is employed with not more } \\
\text { than } 630 \text { German Marks monthly earnings; } 0 \text { otherwise }\end{array}$ \\
\hline Not Employed & Equals 1 if the individual is not employed; 0 otherwise \\
\hline $\begin{array}{l}\text { Not Employed For More Than } \\
\text { Six Months }\end{array}$ & $\begin{array}{l}1 \text { if the individual has been not employed for more than } \\
\text { six months; } 0 \text { otherwise }\end{array}$ \\
\hline Information Level Indicators: & \\
\hline Inhabitant of a Small City & $\begin{array}{l}1 \text { if the individual lives in a city with less than } 20,000 \\
\text { inhabitants; } 0 \text { otherwise }\end{array}$ \\
\hline Inhabitant of a Big City & $\begin{array}{l}1 \text { if the individual lives in a city with more than } \\
100,000 ; 0 \text { otherwise }\end{array}$ \\
\hline
\end{tabular}


Table A.1 continued: Variable Description - Mikrozensus 1995

\begin{tabular}{|c|c|}
\hline Variablename & Description \\
\hline $\begin{array}{l}\text { First-Generation and Second- } \\
\text { Generation Characteristics: } \\
\text { Turkish Nationality }\end{array}$ & $\begin{array}{l}\text { All migrant characteristics are divided into first- and } \\
\text { second-generation groups if not mentioned otherwise. } \\
1 \text { if the individual owns the citizenship of Turkey; } 0 \\
\text { otherwise }\end{array}$ \\
\hline Yugoslavian Nationality & $\begin{array}{l}1 \text { if the individual owns the citizenship of former } \\
\text { Yugoslavia; } 0 \text { otherwise }\end{array}$ \\
\hline $\begin{array}{l}\text { Other (European) Guest Worker } \\
\text { Country Nationality }\end{array}$ & $\begin{array}{l}1 \text { if the individual owns the citizenship of Greece, Italy, } \\
\text { Portugal or Spain; } 0 \text { otherwise }\end{array}$ \\
\hline Other EU Country Nationality & $\begin{array}{l}1 \text { if the individual owns the citizenship of any other EU } \\
\text { country; } 0 \text { otherwise }\end{array}$ \\
\hline CIS or CEEC Nationality & $\begin{array}{l}1 \text { if the individual owns the citizenship of a GUS or } \\
\text { CEEC country; } 0 \text { otherwise }\end{array}$ \\
\hline Other Nationality & $\begin{array}{l}1 \text { if the individual owns the citizenship of any other } \\
\text { country; } 0 \text { otherwise }\end{array}$ \\
\hline Age & Interaction term between foreign nationality and age \\
\hline High Education & $\begin{array}{l}\text { Interaction term between foreign nationality and high } \\
\text { education }\end{array}$ \\
\hline Low Education & $\begin{array}{l}\text { Interaction term between foreign nationality and low } \\
\text { education }\end{array}$ \\
\hline Not Employed & $\begin{array}{l}\text { Interaction term between foreign nationality and not } \\
\text { employed }\end{array}$ \\
\hline $\begin{array}{l}\text { Not Employed For More Than } \\
\text { Six Months }\end{array}$ & $\begin{array}{l}\text { Interaction term between foreign nationality and not } \\
\text { employed for more than six months }\end{array}$ \\
\hline High Education in Origin Country & $\begin{array}{l}1 \text { if a first-generation migrant was older than } 25 \text { years } \\
\text { at immigration and has a high schooling degree }\end{array}$ \\
\hline Low Education in Origin Country & $\begin{array}{l}1 \text { if a first-generation migrant was older than } 14 \text { years } \\
\text { at immigration and has a low schooling degree }\end{array}$ \\
\hline Duration of Stay in Germany & $\begin{array}{l}\text { Duration of Stay in Germany in years for first- } \\
\text { generation migrants }\end{array}$ \\
\hline
\end{tabular}

Notes: Data source is the 1995 wave of the Mikrozensus. See also text for a description of the variables. 
Table A.2: Variable Description - ALLBUS 1996

\begin{tabular}{|c|c|}
\hline Variablename & Description \\
\hline Dependent Variable & $\begin{array}{l}\text { Degree of agreement on the claim „Foreigners are a burden } \\
\text { for the social security system“. Coded 0: no agreement, } 1 \text { : } \\
\text { medium, } 2 \text { : agreement }\end{array}$ \\
\hline \multicolumn{2}{|l|}{ Individual Characteristics: } \\
\hline Age & Age of the respondent in years \\
\hline German Citizen & 1 if the respondent has a German citizenship; 0 otherwise \\
\hline Residing in East Germany & 1 if the respondents lives in Eastern Germany; 0 otherwise \\
\hline Female & 1 if the respondent is female; 0 otherwise \\
\hline Living in a Single Household & 1 if the respondents lives in a single household; 0 otherwise \\
\hline High Degree of Schooling & $\begin{array}{l}1 \text { if the respondents holds a high schooling degree } \\
\text { (Hochschul- or Fachhochschulreife); } 0 \text { otherwise }\end{array}$ \\
\hline Medium Degree of Schooling & $\begin{array}{l}1 \text { if the respondents holds a medium schooling degree } \\
\text { (Mittlere Reife); } 0 \text { otherwise }\end{array}$ \\
\hline Currently Unemployed & $\begin{array}{l}1 \text { if the respondents was unemployed at the time of the } \\
\text { interview; } 0 \text { otherwise }\end{array}$ \\
\hline Employed in Public Sector & $\begin{array}{l}1 \text { if the respondents was employed in the public sector at the } \\
\text { time of the interview; } 0 \text { otherwise }\end{array}$ \\
\hline Currently in School & $\begin{array}{l}1 \text { if the respondents was in school at the time of the } \\
\text { interview; } 0 \text { otherwise }\end{array}$ \\
\hline \multicolumn{2}{|l|}{ Self-Classified Variables: } \\
\hline Right Wing & $\begin{array}{l}1 \text { if the respondent classified himself or herself as having a } \\
\text { right wing attitude; } 0 \text { otherwise }\end{array}$ \\
\hline Left Wing & $\begin{array}{l}1 \text { if the respondent classified himself or herself as having a } \\
\text { left wing attitude; } 0 \text { otherwise }\end{array}$ \\
\hline Fears Loss of Employment & $\begin{array}{l}1 \text { if the respondent reported to be afraid of loosing his job; } 0 \\
\text { otherwise }\end{array}$ \\
\hline \multicolumn{2}{|l|}{ Partner-Specific Variables: } \\
\hline Partner is German Citizen & $\begin{array}{l}1 \text { if the partner of the respondent holds the German } \\
\text { citizenship; } 0 \text { otherwise }\end{array}$ \\
\hline $\begin{array}{l}\text { Partner has been Non-Citizen } \\
\text { at Birth }\end{array}$ & $\begin{array}{l}1 \text { if the partner of the respondent has had another citizenship } \\
\text { at birth; } 0 \text { otherwise }\end{array}$ \\
\hline \multicolumn{2}{|l|}{ Proximity Measure: } \\
\hline Low Share of Foreigners & $\begin{array}{l}1 \text { if the actual share of foreigners residing in the region } \\
\text { (Landkreis) of the respondent was lower than } 8 \% ; 0 \\
\text { otherwise. }\end{array}$ \\
\hline High Share of Foreigners & $\begin{array}{l}1 \text { if the actual share of foreigners residing in the region } \\
\text { (Landkreis) of the respondent was equal or higher than 16\%; } \\
0 \text { otherwise. }\end{array}$ \\
\hline
\end{tabular}

Notes: Originally, there were seven possible categories for the self-classified variables "Right Wing" and "Left Wing". These two variables combine the two extreme categories at each end of the scale. 
Figure 1: The Age Distribution of Immigrants and Natives - Mikrozensus 1995

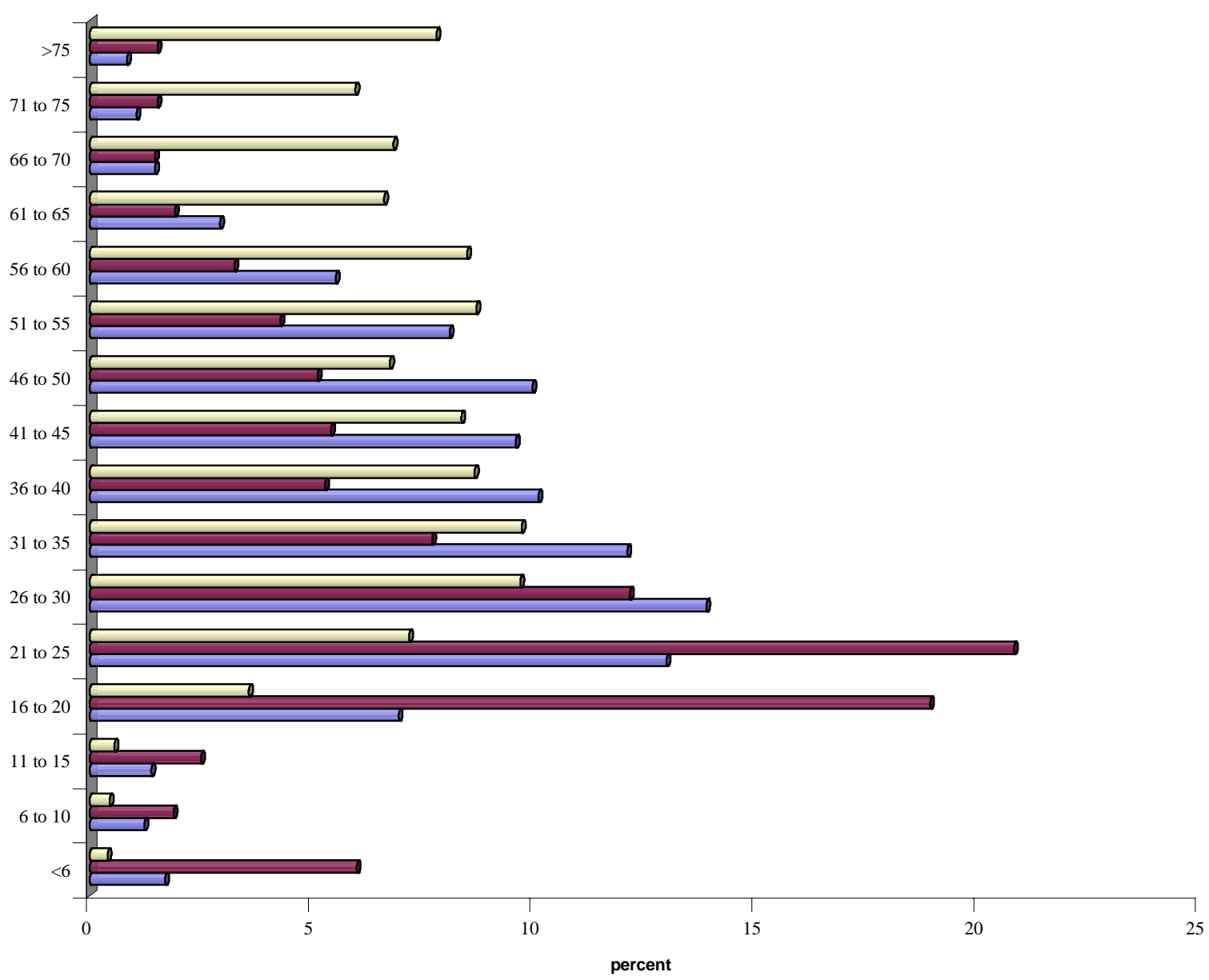

$\square$ First Generation $\square$ Second Generation $\square$ Natives 
Figure 2: Age at Immigration to Germany - Mikrozensus 1995

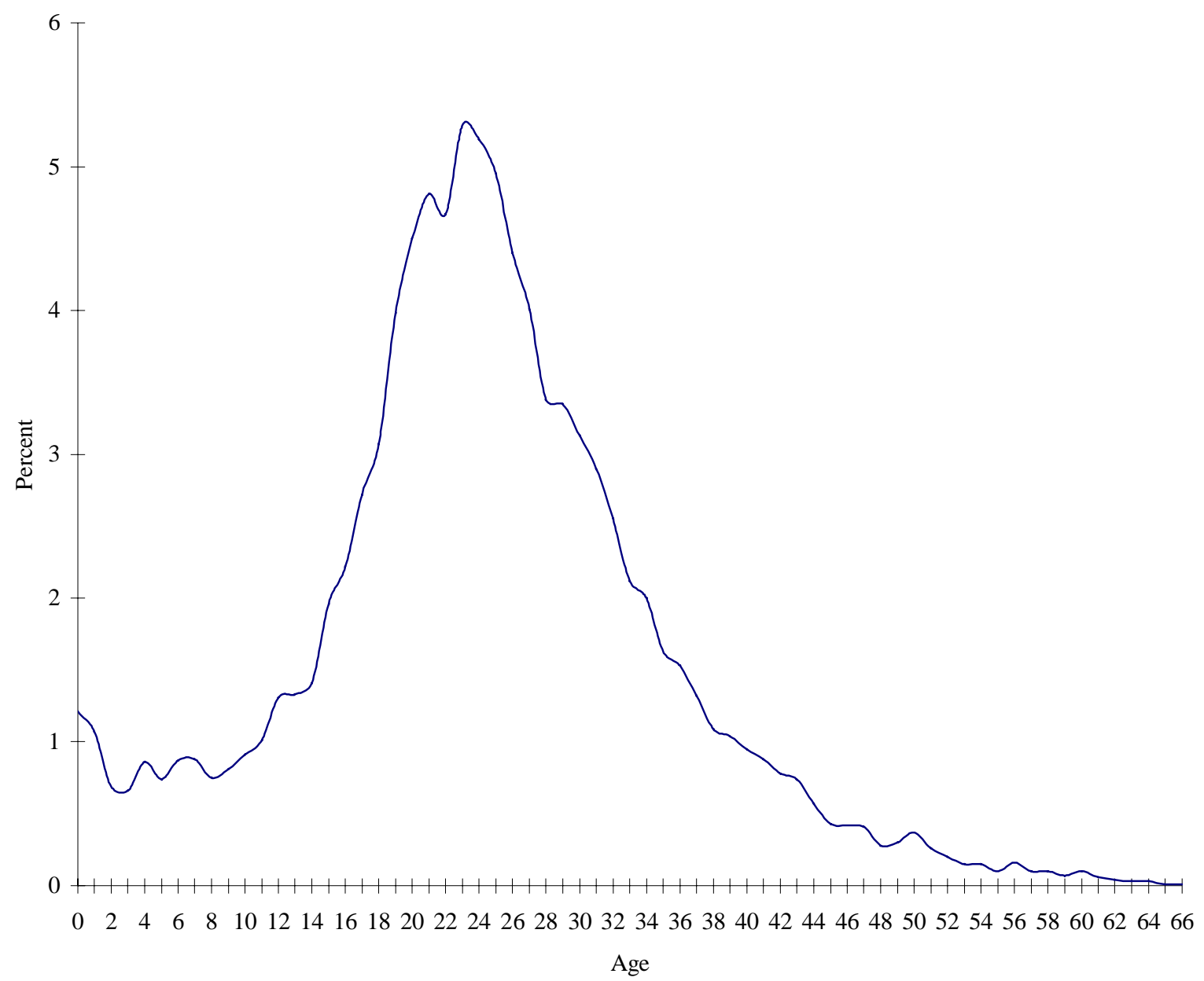


Figure 3: Year of Immigration of 1995 Stock of First-Generation Immigrants - Mikrozensus 1995

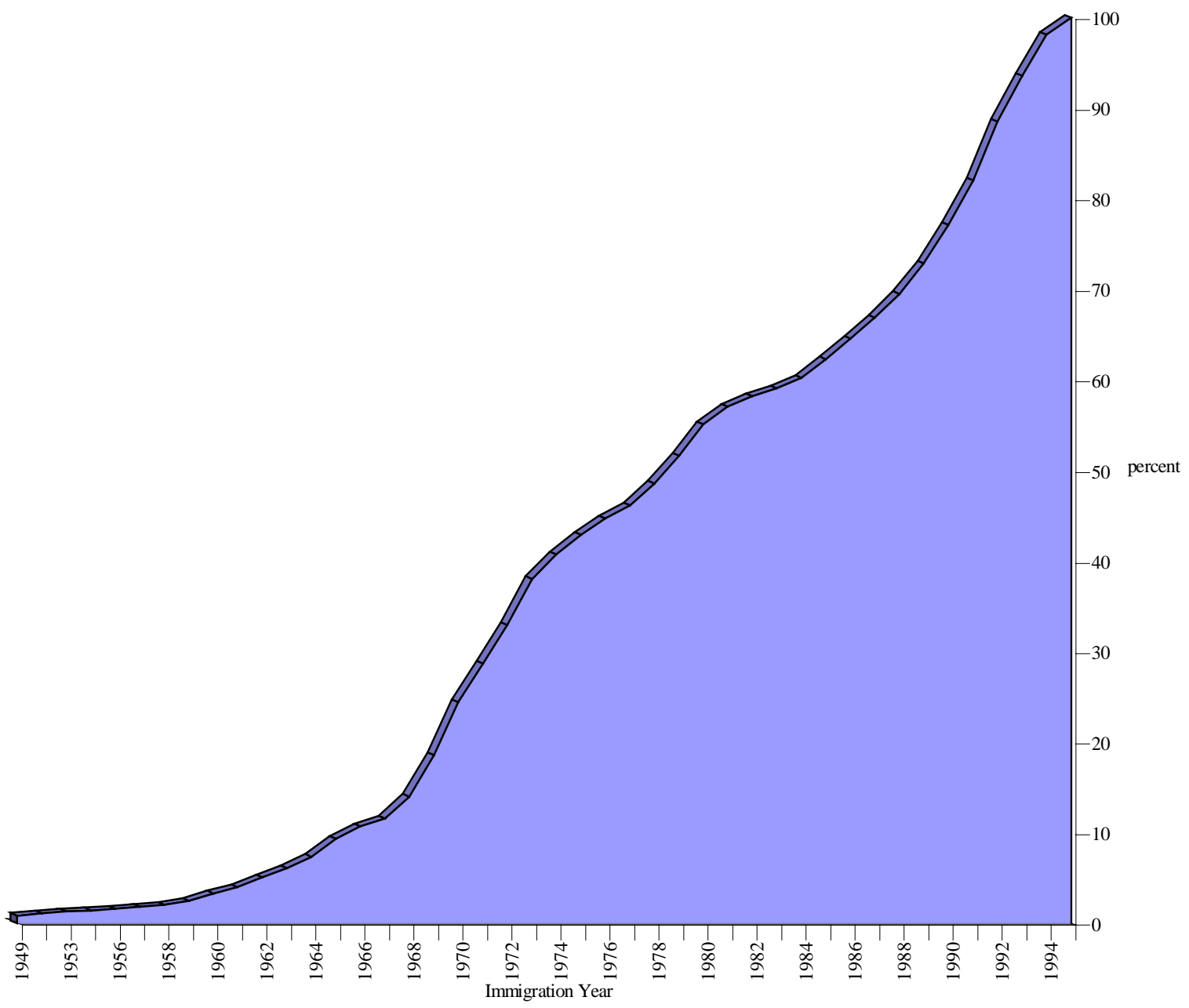


Figure 4: Household Income - Immigrants vs. Natives (Mikrozensus 1995)

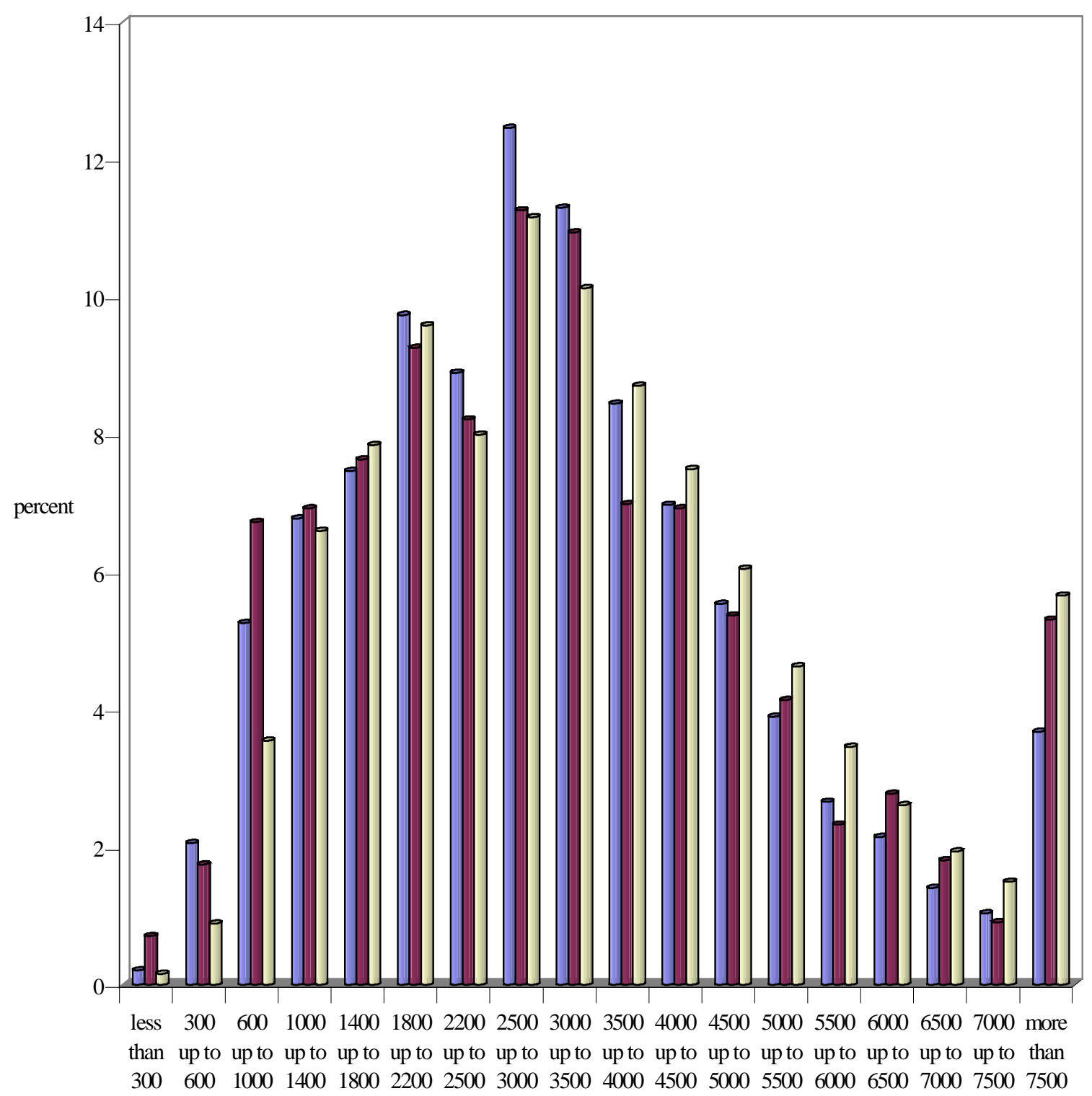

$\square$ first generation family head $\square$ second generation family head $\square$ native family head 


\section{IZA Discussion Papers}

\author{
No Author(s) \\ 201 T. J. Dohmen \\ G. A. Pfann \\ 202 \\ P. Francois \\ J. C. van Ours \\ 203 J. M. Abowd \\ F. Kramarz \\ D. N. Margolis \\ T. Philippon
}

204

G. S. Epstein
A. L. Booth
M. Francesconi
J. Frank

206 C. M. Schmidt

R. Baltussen

R. Sauerborn

207 C. M. Schmidt

208 J. Hartog

R. Winkelmann

209 M. Barbie

M. Hagedorn

A. Kaul

210 T. J. Dohmen

211 A. van Soest

M. Das

X. Gong

212 X. Gong

A. van Soest

P. Zhang

213 X. Gong

A. van Soest

E. Villagomez
Titel

Area

Date

Worker Separations in a Nonstationary Corporate 1

$9 / 00$

Environment

Gender Wage Differentials in a Competitive Labor 5

Market: The Household Interaction Effect

The Tail of Two Countries: Minimum Wages and

5

Employment in France and the United States

$9 / 00$

$9 / 00$

\author{
(1)
}

Labor Market Interactions Between Legal and $\quad 1$

$10 / 00$

Illegal Immigrants

Temporary Jobs: Stepping Stones or Dead Ends? 1

$10 / 00$

The Evaluation of Community-Based Inter-

ventions: Group-Randomization, Limits and

6

$10 / 00$

Alternatives

Arbeitsmarktpolitische Maßnahmen und ihre

6

$10 / 00$

Evaluierung: eine Bestandsaufnahme

Dutch Migrants in New Zealand:

Did they Fare Well?

1

$10 / 00$

Dynamic Effciency and Pareto Optimality in a

3

$10 / 00$

Security

Housing, Mobility and Unemployment

$11 / 00$

A Structural Labour Supply Model with

5

$11 / 00$

Nonparametric Preferences

1

Sexual Bias and Household Consumption: A

5

$11 / 00$

Semiparametric Analysis of Engel Curves in Rural China

Mobility in the Urban Labor Market: A Panel Data Analysis for Mexico 
214 X. Gong

A. van Soest

215 J. Ermisch

M. Francesconi

216 F. Büchel

217 J. Hansen

R. Wahlberg

218 C. Dustmann

A. van Soest

219 F. Kramarz

T. Philippon

220 W. A. Cornelius

E. A. Marcelli

221

C. Grund

222 W.P.M. Vijverberg

223 M. Rosholm

M. Svarer

224 J. Schwarze

225 L. Modesto

J. P. Thomas

226 P. A. Puhani

227

L. Locher

228
G. Brunello
S. Comi
C. Lucifora

229 R. Coimbra

T. Lloyd-Braga

L. Modesto
Family Structure and Female Labour Supply in Mexico City

The Effect of Parents' Employment on Children's

5

Educational Attainment

The Effects of Overeducation on Productivity in

5

$11 / 00$

Germany - The Firms' Viewpoint

Occupational Gender Composition and

5

$11 / 00$

Wages in Sweden

Parametric and Semiparametric Estimation in

1

$11 / 00$

Models with Misclassified Categorical Dependent

Variables

The Impact of Differential Payroll Tax Subsidies

on Minimum Wage Employment

$11 / 00$

The Changing Profile of Mexican Migrants to the 1

$12 / 00$

United States: New Evidence from California and Mexico

Wages as Risk Compensation in Germany

5

$12 / 00$

Betit: A Family That Nests Probit and Logit

$12 / 00$

Wages, Training, and Job Turnover in a SearchMatching Model

Using Panel Data on Income Satisfaction to Estimate the Equivalence Scale Elasticity

An Analysis of Labour Adjustment Costs in Unionized Economies

1

$12 / 00$

On the Identification of Relative Wage Rigidity

Dynamics: A Proposal for a Methodology on Cross-Section Data and Empirical Evidence for Poland in Transition

Immigration from the Eastern Block and the former Soviet Union to Israel: Who is coming when?

The College Wage Gap in 10 European
Unions, Increasing Returns and Endogenous Fluctuations 

the UK 1969-95 
244 S. M. Fuess, Jr. M. Millea

245

F. Andersson

K. A. Konrad

246 E. Plug

W. Vijverberg

247 E. Plug

W. Vijverberg

248 P. M. Picard

E. Toulemonde

249 B. M. S. van Praag

P. Cardoso

250 T. J. Hatton

J. G. Williamson

251 R. Yemtsov

252 R. Yemtsov

253 R. Yemtsov

254 H. Gersbach

A. Schniewind

255 H. Gersbach

A. Schniewind

256 T. Boeri

H. Brücker

257 T. Boeri

258 M. Rosholm

K. Scott

L. Husted

259 A. Ferrer-i-Carbonell

B. M.S. van Praag
Pay and Productivity in a Corporatist Economy:

5

Evidence from Austria

Globalization and Human Capital Formation

5

01/01

Schooling, Family Background, and Adoption:

5

Does Family Income Matter?

Schooling, Family Background, and Adoption:

5

Is it Nature or is it Nurture?

The Impact of Labor Markets on Emergence and

2

Persistence of Regional Asymmetries

"Should I Pay for You or for Myself?"

3

The Optimal Level and Composition of

Retirement Benefit Systems

Demographic and Economic Pressure on

1

01/01

Emigration out of Africa

Labor Markets, Inequality and Poverty in Georgia 4

$01 / 01$

Inequality and Income Distribution in Georgia

4

$01 / 01$

Living Standards and Economic Vulnerability in Turkey between 1987 and 1994

4

$01 / 01$

Learning of General Equilibrium Effects and the Unemployment Trap

3

02/01

Product Market Reforms and Unemployment in Europe

3

02/01

Eastern Enlargement and EU-Labour Markets:

Perceptions, Challenges and Opportunities

2

02/01

Transition with Labour Supply

4

02/01

The Times They Are A-Changin':

1

02/01

Organizational Change and Immigrant

Employment Opportunities in Scandinavia

Poverty in the Russian Federation

4

02/01 
260

P. Cahuc

F. Postel-Vinay

261

M. Lindahl

262 M. Lindahl

263 N. Datta Gupta N. Smith

264 C. Dustmann

265 M. Rosholm M. Svarer

266 C. Dustmann O. Kirchkamp

267 A. Newell

268 A. Newell B. Reilly

269 H. Buddelmeyer

270 B. Augurzky C. M. Schmidt

271 B. Augurzky C. M. Schmidt

272 C. Belzil J. Hansen

273 G. Saint-Paul

274 P. J. Pedersen N. Smith

275 G. S. Epstein T. Lecker
Temporary Jobs, Employment Protection and

Home versus School Learning:

A New Approach to Estimating the Effect of Class Size on Achievement

Summer Learning and the Effect of Schooling:

5

02/01 Evidence from Sweden

Children and Career Interruptions:

5

02/01

The Family Gap in Denmark

Return Migration, Wage Differentials, and the Optimal Migration Duration

Structurally Dependent Competing Risks

The Optimal Migration Duration and Activity

Choice after Re-migration incentives Matter? 
276 B. Amable

D. Gatti

277 R. Winter-Ebmer

278 T. M. Andersen

279 T. M. Andersen

280 P. Apps

R. Rees

281

G. Saint-Paul

282 J. Albrecht

A. Björklund

S. Vroman

283 M. Hagedorn

A. Kaul

V. Reinthaler

284 H. Rapoport

A. Weiss

285

J. Jerger
C. Pohnke
A. Spermann

286 M. Fertig

C. M. Schmidt
The Impact of Product Market Competition on

5

Employment and Wages

Evaluating an Innovative Redundancy-Retraining 6

Project: The Austrian Steel Foundation

Welfare Policies, Labour Taxation and Inter-

2 national Integration

Product Market Integration, Wage Dispersion

2 and Unemployment

Household Saving and Full Consumption over the Life Cycle

7

$04 / 01$

Information Technology and the Knowledge Elites

5

$04 / 01$

Is There a Glass Ceiling in Sweden?

5

04/01

Welfare Analysis in a Schumpeterian Growth Model with Capital

7

$04 / 01$

The Optimal Size for a Minority

1

04/01

Gut betreut in den Arbeitsmarkt?

5

04/01

Eine mikroökonometrische Evaluation der

Mannheimer Arbeitsvermittlungsagentur

First- and Second-Generation Migrants in Germany -What Do We Know and What Do

04/01

03/01

$04 / 01$

$04 / 01$

(1)

People Think 